\title{
Mesoscale simulations of tropical cyclone Enawo (March 2017) and its impact on TTL water vapor.
}

Damien Héron ${ }^{1}$, Stephanie Evan ${ }^{1}$, Joris Pianezze ${ }^{1,2}$, Thibaut Dauhut ${ }^{3}$, Jerome Brioude ${ }^{1}$, Karen Rosenlof ${ }^{4}$, Vincent Noel $^{5}$, Soline Bielli ${ }^{1}$, Christelle Barthe ${ }^{1}$ and Jean-Pierre Cammas ${ }^{1,6}$

5 'Laboratoire de l'Atmosphère et des Cyclones, UMR8105 (Université de La Réunion, CNRS, Météo-France) ${ }^{2}$ Mercator Ocean, Ramonville Saint-Agne, France ${ }^{3}$ Max Planck Institute for Meteorology, Hamburg, Germany

${ }^{4}$ Chemical Sciences Laboratory, Earth System Research Laboratory, NOAA, Boulder, 80305, CO, USA

${ }^{5}$ Laboratoire d'Aérologie, CNRS/UPS, Observatoire Midi-Pyrénées, 14 avenue Edouard Belin, Toulouse, France

$10{ }^{6}$ Observatoire des Sciences de l'Univers de La Réunion, UMS3365 (CNRS, Université de La Réunion, MétéoFrance), Saint-Denis de la Réunion, France

Correspondence to: Stephanie Evan (stephanie.evan@univ-reunion.fr) and Damien Héron (damien.heron@univreunion.fr)

Abstract. In early March 2017, tropical cyclone (TC) Enawo formed north of Réunion Island and moved westward toward Madagascar. Enawo evolved from a tropical depression on 2 March to an intense TC on 6 March. This study explores the water vapor transport into the tropical tropopause layer (TTL) throughout TC Enawo's development. High-resolution ( $2 \mathrm{~km}$ ) mesoscale simulations using the Meso-NH model were performed to cover TC Enawo's lifecycle over the ocean for the period 2-7 March 2017. The simulated convective cloud field agrees with geostationary satellite infrared observations. Compared to the Global Precipitation Measurements (GPM) and Cloud-Aerosol Lidar and Infrared Pathfinder Satellite Observation (CALIPSO) satellite observations, the simulation seems to reproduce well both location and amplitude of the observed precipitation. Simulated and observed ice water content have similar ranges in the upper troposphere but simulated ice above the tropopause is overestimated by a factor 10. Balloon-borne measurements of water vapor, temperature and horizontal winds are also used to validate the Meso-NH simulations in the upper-troposphere and TTL regions. The simulations reveal that the maximum water vapor transport into the TTL occurred on 4 March, when deep (cold) convective clouds were observed. As a result, the lower stratospheric water vapor is increased by $\sim 50 \%$ when compared to pre-storm conditions. An increase of $\sim 2$ ppmv in water vapor mixing ratio was simulated in the lower stratosphere within a 700-km region surrounding Enawo's center. Our simulation of TC Enawo suggests that TCs over the Southwest Indian Ocean $\left(0-30^{\circ} \mathrm{S}, 30-90^{\circ} \mathrm{E}\right)$ could produce a moistening of $0.4 \mathrm{ppmv}$. We extended our results to the global tropics $\left(30^{\circ} \mathrm{S}-30^{\circ} \mathrm{N}\right)$ using the estimates from published work (Allison et al., 2018; Preston et al., 2019) and by calculating statistics on TC numbers and durations using the International Best Track Archive for Climate Stewardship (IBTrACS) dataset. We estimated a global impact of TC induced tropical lower stratospheric moistening of 0.3 to 0.5 ppmv. Our results suggest that TCs may play an important role in the moistening of the TTL/ower stratosphere via direct injection of ice particles and subsequent sublimation.

\section{Introduction}

Water vapor in the low stratosphere regulates up to $10 \%$ of the greenhouse effect at the earth's surface (Solomon et al., 2010). The stratospheric water vapor concentration is primarily affected by the freeze-drying at the tropical tropopause (Brewer, 1949) and the production of water vapor by methane oxidation (le Texier et al., 1988). It has 
been established that freeze-drying process at the cold point temperature of the tropical tropopause is the main

40 driver of the annual and interannual variability in the entry value of stratospheric water vapor (Mote et al., 1996; Randel et al., 2004). On a long-term and global scale, air enters the stratosphere through the tropical tropopause (Brewer, 1949). This air regulates the radiative and chemical balance of the global Upper Troposphere Lower Stratosphere by carrying trace species with it. In the tropics, between $14 \mathrm{~km}$ and $19 \mathrm{~km}$ in altitude, the tropical tropopause layer (TTL), is a transition layer between two different dynamical regimes from rapid vertical transport in the troposphere associated with moist tropical convection to slow ascent in the stratosphere due to the Brewer Dobson circulation. The TTL is often referred to as the "gateway to the stratosphere" for water vapor and other chemical constituents (Fueglistaler et al., 2009). Processes occurring in the TTL control the hydration of the stratosphere (Jensen et al., 2013). The overall contribution due to transport of air by passing the cold trap is not well quantified, but it may contribute during extreme events (e.g. the strong 2016 El Niño; Avery et al., 2017).

50 Very deep convection may overshoot the tropical tropopause $(\sim 17 \mathrm{~km})$, injecting water vapor and ice crystals directly into the stratosphere (Avery et al., 2017; Corti et al., 2008). In addition, overshooting convection plays a critical role in transporting short-lived chemical compounds from near the surface to the lower stratosphere, which is hard to achieve via a large-scale slow ascent (Bergman et al., 2012; Shepherd, 2008).

Dessler et al. (2016) hypothesize that injection of ice into the lower stratosphere could account for 20 to $50 \%$ of

55 the 1 ppmv increase in lower stratospheric water vapor expected in a warming climate. As the role of tropical convection on the Upper Troposphere/Lower Stratosphere (UTLS) composition is still under discussion, observational and modeling studies are needed to further assess the net effect of convection on UTLS water vapor and other short-lived chemical compounds.

Deep convection and in particular overshooting convection have a direct impact on lower stratospheric water

60 vapor. The net effect (hydration or dehydration) will depend on the depth of the injection, the size of the injected ice particles, and the conditions (i.e. relative humidity with respect to ice RHi) of the environment into which the overshoots inject ice (Dauhut et al., 2018; Jensen et al., 2007; Schoeberl et al., 2018; Ueyama et al., 2018) In subsaturated TTL air, condensed ice is not removed quickly enough to produce net dehydration (Jensen et al., 2007). Deep convection associated with tropical cyclones can play an important role in the transport of chemical constituents from the troposphere to lower stratosphere (Ray and Rosenlof, 2007; Zhan and Wang, 2012).

From 23 years of infrared brightness temperature (IR-BT) measurement, Romps and Kuang, (2009) showed that a large fraction of overshooting tropical convection occurs within tropical cyclones (15\% of all the convection that overshoot the tropopause). Using Lagrangian trajectories and airborne measurements, Vogel et al. (2014) showed that the combination of rapid uplift by a typhoon and eastward eddy shedding from the Asian monsoon

70 anticyclone is a fast transport pathway that carries boundary pollutants from Southeast Asia/West Pacific within approximately 5 weeks to the lowermost stratosphere in northern Europe. Analyses of balloon-borne sensors launched from Lhasa, China, in August 2013 show that nearly half of the measured ozone profiles in the upper troposphere were influenced by tropical cyclones occurring over the western Pacific (Li et al., 2017).

Several studies based on model results have also demonstrated that deep convection can efficiently transport water

75 vapor and pollutants to the UTLS (Hassim and Lane, 2010; Jensen et al., 2007; Marécal et al., 2006). Recently, Allison et al. (2018) used high-resolution $(1.33 \mathrm{~km})$ simulations with the Weather Research and Forecasting (WRF) model to investigate the water vapor transport to the UTLS within TC Ingrid (a category 1 storm on the 
Saffir Simpson Scale) in the Gulf of Mexico. They identified dehydration between 14.5 and $17.5 \mathrm{~km}$ due to ice sedimentation and hydration between $\sim 17.5$ and $21 \mathrm{~km}$ due to the sublimation of ice crystals.

80 In addition, Preston et al. (2019) investigated transport of O3/CO/water vapor by typhoon Mireille (a category 3 storm) over the Western North Pacific using the WRF model with chemistry (WRF-Chem). Their high-resolution $(3 \mathrm{~km})$ simulations showed positive vertical fluxes throughout the troposphere and the tropopause, which increased the $\mathrm{CO} /$ water vapor concentration in the UTLS region. Despite having different intensities (category 1 versus category 3 storm), overshooting tops were identified for both systems that transported large quantities of water vapor to the UTLS. Both studies also agree in terms of estimation of net water vapor flux within $50 \%$.

The current study focuses on an intense TC that occurred over the SWIO in March 2017. (Tao and Jiang, 2013) For the period 1979-2008, an average of $\sim 90$ TCs having maximum sustained winds $\geq 63 \mathrm{~km} / \mathrm{h}$ occurred each year globally (cf. Table 2.5 WMO 2017). The most active TC basin is the Western North Pacific (WNP, $30 \%$ of the global total), followed by the Eastern North Pacific (ENP, 19\% of the global total), the Southwest Indian

90 Ocean (SWIO, $\sim 15 \%$ of the global total) and the North Atlantic (NA, $\sim 13 \%$ of the global total). The SWIO has been poorly studied so far despite having tropical-cyclone activity that is comparable to that of the NA. Using 11year Tropical Rainfall Measuring Mission (TRMM) precipitating hydrometeor satellite observations, Tao and Jiang, (2013) identified overshooting tops in tropical cyclones (above $14 \mathrm{~km}$ ) and showed that the South Indian Ocean is the second basin after the Northwest Pacific in terms of total number of overshooting tops (cf. Table 2

95 of Tao and Jiang, 2013).

The event analyzed is the intense TC Enawo (category 3 on the US Saffir Simpson Scale), that made landfall in northeastern Madagascar on 7 March 2017, killing more than 80 people and causing extensive damage. In a previous study, Evan et al. (2020) investigated the effect of deep convection on the TTL composition over the SWIO during austral summer (December-March). They focused on the origin of convective signatures in two

100 balloon-borne water vapor profiles observed in the vicinity of tropical storms in January 2016 (Tropical Storm Corentin) and March 2017 (TC Enawo). The balloon-borne measurements were made in coordination with lidar observation at the Maïdo Observatory on Réunion Island $\left(21^{\circ} \mathrm{S}, 55^{\circ}\right)$. Using lagrangian backtrajectories, convective activity in both tropical storms was shown to produce significant hydration in the upper troposphere (UT). In contrast, no water vapor anomaly was found near or above the tropopause region on 3 March 2017 over

105 Réunion Island as the tropopause region was not downwind of TC Enawo. In addition, the balloon was launched at a distance of $\sim 1000 \mathrm{~km}$ from Enawo when the storm was still intensifying. Results from Allison et al. (2018) and Preston et al. (2019) suggest that overshooting convection and subsequent water vapor transport to the lower stratosphere (LS) mostly occurs in the eyewall region of TCs. Here, we extend the Evan et al. (2020) analysis of TC Enawo using a mesoscale model to quantify the impact of TC Enawo on UTLS water vapor.

110 With a background ranging from 2 ppmv to 6 ppmv (Fueglistaler et al., 2009; Rosenlof et al., 2001), the water vapor content in the TTL is very sensitive to small variations. Most GCMs with coarse horizontal and vertical grid spacings underestimate convective transport and its effect on UTLS water vapor. High-resolution modeling allows a better representation of deep convection within TCs and is therefore useful to understand the relative roles of vertical transport of and ice microphysics on UTLS water vapor (Allison et al., 2018; Chaboureau et al.,

115 2007; Dauhut et al., 2015; Frey et al., 2015; Mrowiec et al., 2012; Ravindra Babu et al., 2015). The main goal of this study is to further our understanding of the impact of TC on the TTL by simulating the TC Enawo over the SWIO basin, for the period 2-7 March 2017 when the storm was intensifying from tropical storm to intense tropical 
cyclone. over the SWIO. We take advantage of the Meso-NH model that has been previously developed for the simulations of TCs in the SWIO (Hoarau et al., 2018; Pianezze et al., 2018). This study is also part of the CONCIRTO (CONvection CIRrus over the Tropical indian Ocean) project that aims to further our knowledge on how deep convection and cirrus clouds affect the TTL over the SWIO.

The present paper is organized as follows. Section 2 describes the Meso-NH model setup as well as balloon-borne in situ measurement and satellite observations used to evaluate the model representation of TC Enawo. Section 3 presents an overview of the evolution of TC Enawo in both observations and simulations. Section 4 investigates simulated water and ice transport to the low stratosphere. The global impact of TCs to the tropical lower stratospheric water vapor is assessed in Section 5. The model results are discussed in Section 6. Finally, Section 7 contains the conclusions and a summary of our study.

\section{Observations and Mesoscale model}

\subsection{Satellite observations}

130 METEOSAT 8 is a geostationary satellite located at $41.1^{\circ} \mathrm{E}$ that monitors for the Indian Ocean since March 2017. The Brightness Temperatures (BT) of the infrared channel at $10.8 \mu \mathrm{m}$ are used to identify deep convective clouds within TC Enawo and validate their representation in the Mesoscale simulations. METEOSAT 8 data used in this study are provided by National Oceanic and Atmospheric Administration National Centers for Environmental Prediction (NCEP) and correspond to globally merged $\left(60^{\circ} \mathrm{S}-60^{\circ} \mathrm{N}\right)$ infrared BT from various geostationary

135 satellites (John Janowiak, 2017). They have a temporal resolution of 30 minutes and a horizontal resolution of 4 $\mathrm{km}$.

The Global Precipitation Measurement Integrated Multi-satellitE Retrievals (GPM-IMERG) product from the National Aeronautics and Space Administration (NASA) is used to evaluate simulated rainfall. It uses an algorithm that merges precipitation radar, microwave precipitation estimates, microwave-calibrated infrared, and

140 rain gauge analyses at a spatial resolution of $0.1^{\circ}$ over the latitudinal belt $60^{\circ} \mathrm{N}-60^{\circ} \mathrm{S}$ (Huffman et al., 2018). The GPM-IMERG product has a temporal resolution of 30 minutes.

Measurements from the Cloud and Aerosol Lidar with Orthogonal Polarization (CALIOP) lidar onboard the Cloud-Aerosol Lidar and Infrared Pathfinder Satellite Observation (CALIPSO) satellite are used to validate the distribution of simulated ice clouds in the UTLS. Original CALIOP observations correspond to backscatter measurements at $532 \mathrm{~nm}$ and $1064 \mathrm{~nm}$ since June 2006 (Level 1 data). CALIOP Level 2 data (version V4.10) contain extinction and Ice Water Content (IWC) profiles at 60-m vertical and 5-km horizontal resolutions, which are retrieved from the 532-nm extinction coefficient (Avery et al., 2012). Between March 2 and 7, there were 9 CALIPSO overpasses over TC Enawo. However, only the overpass on 5 March at 21:30 UTC was over TC Enawo's eye region (cf. Figure 7).

\subsection{Balloon-borne observations.}

A balloon launch was specifically planned using a Lagrangian model and geostationary infrared images to sample the convective outflow from TC Enawo on 3 March 2017 at 18 UTC. The balloon sonde payload consisted of the Cryogenic Frostpoint Hygrometer (CFH) as well as the Intermet iMet-1-RSB and Meteomodem M10 meteorological radiosondes. A detailed description of the balloon measurements is provided in Evan et al. (2020). 
155 The Cryogenic Frost Point Hygrometer (CFH) is an in-situ instrument that measures the water vapor mixing ratio profile from the surface to the stratosphere $(\sim 28 \mathrm{~km})$.

The CFH was developed to provide highly accurate water vapor measurements in the TTL and stratosphere where the water vapor mixing ratios are extremely low $(\sim 2 \mathrm{ppmv})$. CFH mixing ratio measurement uncertainty ranges from $5 \%$ in the tropical lower troposphere to less than $10 \%$ in the stratosphere (Vömel et al., 2007) ; a recent study shows that the uncertainty in the stratosphere can be as low as 2-3\% (Vömel et al., 2016). The M10 radiosonde provides measurements of Relative Humidity (RH), temperature, pressure, vertical velocity, wind speed and direction from which zonal/meridional winds are derived.

\subsection{Meso-NH model}

Simulations of TC Enawo were performed with the Mesoscale, anelastic, and nonhydrostatic model Meso-NH version 5.3 (Lac et al., 2018). Recent Meso-NH simulations have been used successfully to study tropical storms/cyclones over the SWIO (Barbary et al., 2019; Hoarau et al., 2018; Lac et al., 2018; Pianezze et al., 2018). Meso-NH has also been used to study overshooting convection and stratospheric hydration (Chaboureau et al., 2007; Dauhut et al., 2015).

Different simulations (Table 1), were performed with the Meso-NH model. The simulations have vertical grid

170 spacings less than $100 \mathrm{~m}$ in the boundary layer and $300 \mathrm{~m}$ up to $30 \mathrm{~km}$ ( 140 verticals levels), with a damping layer in the uppermost $25 \mathrm{~km}$ and a model top at $1 \mathrm{hPa}$. All simulations are initialized and forced at the boundaries with 6-hourly analyses from the operational European Centre for Medium Range Weather Forecasts - Integrated Forecast System (ECMWF-IFS) with a grid spacing of $\sim 9 \mathrm{~km}$ and 137 vertical levels. Simulations were run from 2 March 2017, 00UTC to 7 March, 00UTC to encompass Enawo's evolution from tropical depression to very

175 intense TC just before landfall over Madagascar. The turbulent scheme is based on Cuxart et al. (2000). We use a single-moment bulk mixed-phase cloud parameterization ICE3 (Lac et al., 2018; Pinty and Jabouille 1998). It solves the microphysics of five hydrometeors which are three precipitable species (snow, rain, and graupel) and two non-precipitating hydrometeors (cloud water, and cloud ice). The longwave radiative scheme used in MesoNH is the rapid radiation transfer model (RRTM; Mlawer et al., 1997). The shortwave radiative scheme is based on Foucart and Bonnel (1980). The subgrid shallow convection is based on the eddy-diffusivity mass flux and Kain-Fritsch approach of entrainment and detrainment in cumulus clouds (Pergaud et al., 2009). Meso-NH is coupled with the surface model SURFEX (Surface Externalisée, Masson et al., 2013) and uses COARE-3 parameterisation for ocean-atmosphere fluxes (Fairall et al., 2003). The first model level is at $10 \mathrm{~m}$.

Initial simulations were run to test the model's sensitivity to different parameterizations on a domain A covering $46^{\circ} \mathrm{E}-69^{\circ} \mathrm{E}$ in longitude, $32^{\circ} \mathrm{S}-8^{\circ} \mathrm{S}$ in latitude at a horizontal grid-spacing of $10 \mathrm{~km}$ (Simulation S1). Tests on domain limits have been performed to identify the sensitivity to the eastern boundary. Then, five simulations were performed (Table 1) to test the horizontal resolution, nested domains and sensitivity to SST. Simulations were run in domain A with a horizontal grid-spacing of $10 \mathrm{~km}$ and $5 \mathrm{~km}$ (Simulations S1 and S2). The Kain Fritsch cumulus parameterization was used to simulate deep convection in S1 and S2. A second domain, called domain B, centered over a region that encompasses Enawo's life cycle was designed (Figure 1) for simulations with a horizontal gridspacing of $2 \mathrm{~km}$ (Simulations S3, S4 and S5). Deep convection was explicitly resolved at that resolution. Simulation S3 had nested domains having grid spacings of 10 (domain A) and $2 \mathrm{~km}$ (domain B). It was found that using one-way grid-nesting did not improve the model's representation of Enawo, so higher resolution simulations 
at $2 \mathrm{~km}$ were run without nesting (Simulations S4, S5). The sensitivity to the Sea-Surface-Temperature (SST) was also tested. In simulations S1 to S4, the Sea-Surface-Temperature (SST) data from ECMWF were used and updated every 6 hours. Simulation S5 is coupled with the oceanic model CROCO (Coastal and Regional Ocean COmmunity model, http://www.croco-ocean.org, (Debreu et al., 2012; Penven et al., 2006). Further details on the coupling are provided in Voldoire et al. (2017) and Pianezze et al. (2018). The oceanic model has a horizontal resolution of $2 \mathrm{~km}$ and 32 vertical levels from the surface to the ocean bottom (about a depth of $5 \mathrm{~km}$ below Enawo) and shares the same domain of simulation as the Meso-NH model.

\section{Evolution of TC Enawo}

\subsection{TC Enawo (March 2017)}

The Madden Julian Oscillation (MJO) was active at the end of February and during the first week of March 2017 with a signal centered over Africa and the Indian Ocean. Favored by the MJO active phase and the arrival of an equatorial Rossby wave, Enawo initially formed as a tropical disturbance on March 2 with 10-minute maximum sustained wind speeds $\sim 40 \mathrm{~km} . \mathrm{h}^{-1}$. The Regional Specialized Meteorological Center (RSMC) La Réunion, in charge of TC's forecasts for the SWIO, named the storm Enawo on 2 March 2017 at 00 UTC. The best track data used in this study are provided by RSMC La Réunion.

In the SWIO, different stages of TCs are defined using a 10-min maximum sustained as follows: Tropical

210 Depression (TD, $<17.4 \mathrm{~m} \mathrm{~s}-1$ ), Moderate Tropical Storm (MTS, $\geq 17.4 \mathrm{~m} \cdot \mathrm{s}^{-1}$ ), Severe Tropical Storm (STS, $\geq$ $24.6 \mathrm{~m} . \mathrm{s}^{-1}$ ), Tropical Cyclone (TC, $\geq 32.9 \mathrm{~m} \cdot \mathrm{s}^{-1}=$ Category 1 on the US Saffir-Simpson Scale), Intense TC (ITC, $\geq 43.6 \mathrm{~m} \cdot \mathrm{s}^{-1}$, Categories 2-3 on the US Saffir-Simpson Scale) and Very Intense TC (VITC, $\geq 59.6 \mathrm{~m} \cdot \mathrm{s}^{-1}$, Categories 4-5 on the US Saffir-Simpson Scale).

Between 2 and 4 March, Enawo intensified slowly from TD to TS because of a strong east-southeast vertical wind shear. On 4 March, Enawo stalled over the ocean while intensifying. Very cold cloud tops $\left(<-90^{\circ} \mathrm{C}\right)$ were observed at that time. Enawo evolved from TS to TC on 5 March at 06UTC with an eyewall with a poorly defined structure. Later, the intensification speed was slowed by an Eyewall Replacement Cycle (ERC), observed on satellite microwave images. An ERC occurs when the pressure forces at the center of the TC push inward the eyewall. At some point, the eyewall collapses and a new eyewall forms afterward. Because of a decrease in vertical wind shear, Enawo further intensified to reach the ITC stage on 6 March at 12UTC (Category 2-3 on the Saffir-Simpson scale), with 10-minute maximum sustained winds of $46.3 \mathrm{~m} \mathrm{~s}-1$ (90kts). The 10-minute maximum sustained winds (VMAX) increased by $23 \mathrm{~m} \cdot \mathrm{s}^{-1}$ (45 kts) in 24 hours, larger than the top 5\% percentile of rapid intensification over the SWIO basin (Leroux et al., 2018). Enawo reached peak intensity on 7 March at 06 UTC, with ten-minute maximum sustained winds at $56.5 \mathrm{~m} \cdot \mathrm{s}^{-1}(110 \mathrm{kts})$ and the central pressure at $932 \mathrm{hPa}$. TC Enawo reached Madagascar's northeastern coast on March 7 at around 09:30 UTC and was the third strongest tropical cyclone on record to strike the island. It was also the strongest TC of the Southern Hemisphere for the 2016/2017 TC season. The RSMC La Réunion provides 6-hourly best-track data that include the location of the storm center, minima of mean sea level pressure (MSLP) and 10-min maxima sustained wind. Root mean square errors (RMSE) between the Best Track and the simulations were calculated for track (in km) and MSLP (in hPa) following the approach of Chandrasekar and Balaji (2012) and Allison (2018). The RMSE for the track and MSLP for each simulation are presented in Table 1. Based on the results of MSLP and RMSE, simulation S4 does a better job in representing 
the intensification phase and the trajectory of Enawo. The comparison of S4 to Enawo's best track, precipitation and balloon-borne measurements are presented in the subsequent sections. Simulation S4 will be used in section 4 to investigate the vertical structure of the TTL and water vapor/ice transport to the lower stratosphere.

\subsection{Trajectory/intensification}

Figure 1 compares the simulated trajectory of simulation S4 to the best-track data from March 2 at 06UTC (top right) and March 7 at 00 UTC (bottom left). The trajectory in the simulations is defined using a minimum of Mean Sea Level Pressure (MSPP). The simulated trajectory is to the south of the one provided in the best-track data but with a RMSE of $97 \pm 54 \mathrm{~km}$. After March 4, the simulated trajectory is even more to the south when compared to the best track. However, the westward propagation of the tropical cyclone is relatively well represented with comparable propagation speed. On March 4, the simulation was able to show that Enawo stalled over the ocean near $13.6^{\circ} \mathrm{S} / 56.5^{\circ} \mathrm{E}$. In the rest of the study, we use the minimum MSLP to define the storm center.

Figure 2 compares Enawo's simulated intensity (MSLP) with the corresponding RSMC La Réunion best-track data. Enawo's intensity is relatively well represented in the simulation in the first 60 hours of the run (2,3 and 4 March). The simulation has a RMSE for MSLP less than $6 \mathrm{hPa}$. Since no nudging was applied, it is remarkable that the Meso-NH simulations can represent Enawo's initial development from tropical depression on 2 March, 00UTC to moderate tropical storm on 3 March, 18UTC. This is most likely due to the high-resolution operational ECMWF analyses used for initialization and the fact that the initial storm structure was present in the ECMWF analysis on 2 March 00UTC. When initialized a few days before, the Meso-NH did not generate the initial tropical

250 depression that would become TC Enawo.

On 5 March 00UTC, Enawo stalled over the ocean after the ERC. The ERC was not reproduced by the simulation and the simulation started to diverge compared to Enawo's MSLP. An ERC is particularly difficult to simulate and a resolution less than $500 \mathrm{~m}$ is necessary to resolve this process (S. Bielli, personal communication). Between $60 \mathrm{~h}$ and $96 \mathrm{~h}$, the intensification is slower in the simulation as indicated by the slower decrease in the simulated MSLP. After 96h (6 March, 00 UTC), the rapid intensification when Enawo evolves from TC to intense TC is shown in the best-track data with a drop of $30 \mathrm{hPa}$ in the MSLP over $12 \mathrm{~h}$. The model is not able to capture this rapid intensification but instead simulates a steady intensification phase. As a consequence, the error in the MSLP increases to $20 \mathrm{hPa}$ at the end of the simulation.

\subsection{Precipitation}

260 Figure 3 displays a comparison of GPM observed rainfall (left) to the one simulated in the S4 simulation (right). For this comparison, simulated precipitation was interpolated to the GPM grid $\left(0.1^{\circ} \mathrm{x} 0.1^{\circ}\right)$ and integrated over the period 2 March, 06 UTC to 7 March, 00 UTC. Overall, the simulated total rainfall agrees with observations and Meso-NH captures the north-south asymmetry.

Between March 4 and March 5, heavy rain (in red on Figure 5) is observed in the eyewall. Precipitation for this

265 period tends to be overestimated in the S4 simulation. Precipitation within the secondary rainbands are consistent with those observed, especially south of Enawo's trajectory. The model tends to produce lighter precipitation over a larger region. In addition, simulated precipitation over the eastern coast of Madagascar is not observed in the GPM data. 


\subsection{Comparison to balloon-borne measurements.}

270 We further compare the Meso-NH model results to balloon-borne measurements at the Maïdo Observatory on 3 March 2017 at 18 UTC. At the time of the balloon launch at the Observatory, Enawo was a tropical storm located near $13^{\circ}$ south latitude and $56.42^{\circ}$ east longitude, about $900 \mathrm{~km}$ northwest of Réunion Island. For this comparison, the model fields of water vapor mixing ratio, temperature, zonal and meridional winds are interpolated onto the balloon's location and put on a regular 200-m vertical grid. Comparisons between the simulated profiles and

$275 \mathrm{CFH} / \mathrm{M} 10$ radiosondes are shown on Figure 4. The CFH water vapor profile has fine-scale structures at 6 and $10 \mathrm{~km}$ which are not reproduced in the simulation (Figure 4, right).

The detrainment of water vapor at $\sim 13 \mathrm{~km}$ is resolved in the simulation but remains lower than the observed one. In the troposphere between 2 and $14 \mathrm{~km}$ in altitude, the simulation has a wet bias of $+450 \mathrm{ppmv}$, resulting from a higher moisture transport with an explicit representation of convection at a $2 \mathrm{~km}$ grid-spacing. In the TTL (14-

$18 \mathrm{~km}$ in altitude), the mean water vapor difference at the location of the Maïdo Observatory is about $-1 \mathrm{ppmv}$ in S4.

The simulated temperature profile is colder than the M10 temperature profile in the troposphere between 2 and $14 \mathrm{~km}$ with a mean bias of $-1 \mathrm{~K}$. A cold bias of $-2 \mathrm{~K}$ is also observed in TTL (14-18 km). However, both the model and the observation indicate a CPT at $\sim 16 \mathrm{~km}$.

285 On Figure 4, the simulated and observed profiles of zonal and meridional wind speed are in good agreement. The peak in meridional wind at $13 \mathrm{~km}$ associated with Enawo's convective outflow in the UT is captured by the model.

\subsection{Infrared brightness temperature}

Figure 5 compares simulated (top panel) and observed (bottom panel) infrared Brightness Temperatures (BT) at different stages of Enawo's lifecycle. The simulated infrared BT is estimated using the RTTOV-v11 radiative model RTTOV-v11 (Saunders et al., 2018; Senf and Deneke, 2017). Infrared BTs are shown on 3 March, 18 UTC (time of the balloon launch, left panels), 4 March 12 UTC (middle panels) and 5 March 21:30 UTC (right panels). March 4 and 5 correspond to days of intensifying convection within Enawo that became a TC on 5 March at 12UTC. The simulated horizontal structure of Enawo is relatively well represented when compared to the METEOSAT 8 satellite images.

295 The development of convective clouds is slightly delayed by a few hours in the simulation and the eyewall region is not as well defined as in the observation. On 3 March 18 UTC, the simulation overestimates convection over the eastern part of the domain. On 4 March 12 UTC, Enawo's deepest (coldest infrared BT) convective clouds are located north of $15^{\circ} \mathrm{S}$. Simulated convective clouds are $2^{\circ} \mathrm{C}$ colder than the observed ones which suggest higher convective clouds than observed. In the simulation, the coldest infrared brightness temperatures range from $-85^{\circ} \mathrm{C}$ (March 2) to $-92^{\circ} \mathrm{C}$ (March 4\&6) while the METEOSAT 8 infrared BT range from $-80.5^{\circ} \mathrm{C}$ to $-90^{\circ} \mathrm{C}$.

On March 5 at 21:30 UTC, the spiral rainbands are not as well defined in the simulation as clouds are more scattered than in the observation. Simulated convective clouds are overestimated in the northwest quadrant while they are underestimated in the southeast quadrant of the storm. Cold infrared BTs are observed in the simulated TC rainband which suggest the existence of updraft in the simulation. There was a CALIPSO overpass over the 305 eyewall on 5 March, 2130 UTC (orange lines on Figure 7) and the distribution of simulated ice is presented in the subsequent section. 


\section{Results}

\subsection{Vertical structure in the TTL.}

Figure 6 represents an along-track cross-section (latitude versus altitude) comparing IWC profiles from the

CALIOP observations to the Meso-NH simulation. The simulated IWC variable includes both cloud ice and precipitating snow which are prognostic variables of the ICE 3 microphysics scheme. The cross-section of IWC is shown for CALIPSO's orbit track on 5 March 21:30 UTC, crossing Enawo's eye region. At that time, Enawo was a severe Tropical Storm and the position of the simulated storm agrees with the geostationary satellite image valid at that time. On Figure 6, the mean cold point tropopause in the simulation is at $16.5 \mathrm{~km}$ and is indicated in

315 black on both panels.

The CALIOP lidar cannot penetrate deep convective clouds, therefore observed IWC is not shown below $\sim 10 \mathrm{~km}$. From the distribution of IWC on Figure 8, we can see that the model tends to produce less ice in the convective core below $\sim 15 \mathrm{~km}$ in altitude, and more ice above. On the contrary, less ice is produced in the upper troposphere in Enawo's outer regions (south of $18.5^{\circ} \mathrm{S}$ and north of $11^{\circ} \mathrm{S}$ ). In the upper troposphere, IWC values range from $10^{-4}$ to $10^{-2} \mathrm{~g} \cdot \mathrm{m}^{-3}$ in both the observation and the simulation. Maximum values of IWC are observed in the eyewall: $\sim 0.01$ to 0.05 g. $\mathrm{m}^{-3}$ in the observation versus $\sim 0.05$ to $0.1 \mathrm{~g} \mathrm{~m}^{-3}$ in the simulation. Simulated IWC is a factor 10 larger than CALIPSO IWC above the CPT. The location of the convective center is fairly well reproduced by the simulation $\left(13^{\circ} \mathrm{S}, 55^{\circ} \mathrm{E}\right.$ in $\mathrm{S} 4$ versus $14^{\circ} \mathrm{S}, 54.7^{\circ} \mathrm{E}$ in the CALIPSO observation). The simulation does show ice above the CPT between 11 and $15^{\circ} \mathrm{S}$ (IWC ranging from $10^{-5}$ to $10^{-4} \mathrm{~g} \cdot \mathrm{m}^{-3}$ ). However, CALIOP only shows ice above the CPT in the eye region (according to the best-track data the storm center was located at $13.96^{\circ} \mathrm{S}, 55.02^{\circ} \mathrm{E}$ on 5 March, 18 UTC).

Average mass $\left(\varphi_{\text {mass }}\right)$, ice $\left(\varphi_{\text {ice }}\right)$ and water vapor $\left(\varphi_{\text {vapor }}\right)$ flux density $\left(\mathrm{kg} \cdot \mathrm{m}^{-2} \cdot \mathrm{s}^{-1}\right)$ to the low stratosphere $(\sim 18 \mathrm{~km})$ can be computed as a function of time and distance from the TC center using the equations:

330

$$
\begin{aligned}
& \varphi_{\text {mass }}=\frac{\left(\sum_{r_{i}<r_{k}}^{r \leq r_{k+1}} \rho\left(r_{i}\right) w\left(r_{i}\right)\right)}{N_{k}} \\
& \varphi_{\text {ice }}=\frac{\left(\sum_{r_{i}<r_{k}}^{r \leq r_{k+1}} \rho\left(r_{i}\right) w\left(r_{i}\right) q_{i c e}\left(r_{i}\right)\right)}{N_{k}} \\
& \varphi_{\text {vapor }}=\frac{\left(\sum_{r_{i}<r_{k}}^{r \leq r_{k+1}} \rho\left(r_{i}\right) w\left(r_{i}\right) q_{\text {vapor }}\left(r_{i}\right)\right)}{N_{k}}
\end{aligned}
$$

$r_{i}$ corresponds to a model grid point, $\rho$ is the air density $\left(\mathrm{kg} \cdot \mathrm{m}^{-3}\right)$, $\mathrm{q}_{\text {ice }}$ is the ice mixing ratio $\left(\mathrm{kg} \mathrm{kg}^{-1}\right), \mathrm{q}_{\text {vapor }}$ is the water vapor mixing ratio $\left(\mathrm{kg}_{\mathrm{kg}} \mathrm{kg}^{-1}\right)$ and $\mathrm{w}$ is the vertical velocity $\left(\mathrm{m} . \mathrm{s}^{-1}\right)$. Figure 7 illus trates the calculation of $\varphi_{\text {mass }}$ and can be applied to $\varphi_{\text {ice }}$ and $\varphi$ vapor by adding the $q_{\text {ice }} / q_{\text {vapor }}$ term. We sum the $\rho \times w$ term at individual grid point over ring circle regions around the TC center (red symbol on Figure 7) defined by radiuses $\left(r_{k}\right)$ varying from 20 to $700 \mathrm{~km}$ by $20 \mathrm{~km}$ increment (ie., $\mathrm{r}_{\mathrm{k}+1^{-}} \mathrm{r}_{\mathrm{k}}=20 \mathrm{~km}$ ) and divide by the number $\mathrm{N}_{\mathrm{k}}$ of grid points in the ring circle

340 region to define average $\varphi_{\text {mass }}, \varphi_{\text {ice }}, \varphi_{\text {vapor }}\left(\mathrm{kg} \cdot \mathrm{m}^{-2} \cdot \mathrm{s}^{-1}\right)$. Some studies have proposed to calculate upward flux using only grid points containing upward vertical motion (Chaboureau et al., 2007; Dauhut et al., 2016; Mrowiec et al., 2012). Wei, (1987) has estimated mass transport across the tropopause by looking at the contribution from diabatic processes, the temporal change of the tropopause potential temperature and mass exchange due to the potential temperature gradient along the tropopause (Ravindra Babu et al., 2015; Wei, 1987). 
345 The maximum mass flux density is simulated on 4 and 6 March around 00 UTC within $\sim 100 \mathrm{~km}$ of the TC center (eye and eyewall regions) with values ranging from 0.5 to $1 \times 10^{-3} \mathrm{~kg} \cdot \mathrm{m}^{-2} \cdot \mathrm{s}^{-1}$. Similarly, the maximum water vapor flux density is observed on 4 and 6 March, with values ranging from 1.5 to $2.5 \times 10^{-8} \mathrm{~kg} \cdot \mathrm{m}^{-2} \cdot \mathrm{s}^{-1}$. Large negative values are simulated on 4 March at 12UTC for both mass and water vapor fluxes density. During the same time period, sporadic transport of ice across $18 \mathrm{~km}$ is simulated within a $300 \mathrm{~km}$ region around Enawo's center. At that time, Enawo was still forming and thus updraft regions were more scattered within the storm. TC Enawo stalled over the ocean on March 4\&5 and intensified (Figures 1\&2). An enhancement of ice flux in the eye/eyewall regions (150 km around the TC center) can be observed on those days which is consistent with high (cold) convective clouds observed on Figure 5. After March 5, the ice flux at $18 \mathrm{~km}$ decreased although the observed storm reached peak intensity on 7 March. Comparison of the ice and water vapor fluxes on Figure 8, clearly indicates that positive water vapor flux density into the stratosphere doesn't necessary mean direct injection of ice, and vice versa.

\subsection{Overshooting convection on 4 March.}

As indicated on Figure 8, positive ice flux to the LS was observed on 4 March, when the storm was intensifying over the ocean. In this section, we show an example of an overshooting convective event that occurred on 4 March between 11:55 UTC and 12:45 UTC (Figure 9). Figure 9 depicts north to south cross sections (at longitude $56.09^{\circ} \mathrm{E}$ ) through the simulated overshooting cloud on 4 March. Simulated higher vertical velocity near $13.4^{\circ} \mathrm{S}$ is coherent with the location of the storm center in the best-track data $\left(13.65^{\circ} \mathrm{S}, 56.85^{\circ} \mathrm{E}\right.$ on $\left.4 \mathrm{March}, 12 \mathrm{UTC}\right)$. At 11:55 UTC, vertical winds in the lower TTL troposphere $(14-16.5 \mathrm{~km})$ are relatively weak. The $380 \mathrm{~K}$ isentropic surface (black lines on Figure 9) is deformed, possibly due to eddies or convectively generated gravity

365 waves. A dry layer can be observed below $380 \mathrm{~K}$, which is linked with the cold point tropopause. Higher values of water vapor mixing ratio $\sim 20$ ppmv above the tropopause could be due to a precedent overshooting event within Enawo.

At 12:05 UTC, a stronger updraft develops near $13.5^{\circ} \mathrm{S}$ which further deforms the $380 \mathrm{~K}$ isentropic surface. Direct ice injection can be seen between $17 \mathrm{~km}$ and $19 \mathrm{~km}$ (ice mixing ratio of $10 \mathrm{ppmv}$ to $1000 \mathrm{ppmv}$ at $18 \mathrm{~km}$ ) and

370 dehydration below the tropopause between $13.4^{\circ} \mathrm{S}$ to $13.6^{\circ} \mathrm{S}$ becomes more important.

At 12:15 UTC, stronger upward motion and tropopause's deformation are still observed. The water vapor mixing ratio above $380 \mathrm{~K}$ increases from $15 \mathrm{ppmv}$ to more than $45 \mathrm{ppmv}$.

10 minutes later, at 1225 UTC ice mixing ratio values decrease by a factor of 100 in the lower stratosphere (17$\left.19 \mathrm{~km}, 13.4^{\circ} \mathrm{S}-13.6^{\circ} \mathrm{S}\right)$ while water vapor mixing ratios increase by a factor 4 compared to the initial condition ( 40 versus $10 \mathrm{ppmv}$ initially). This suggests that ice was transported in the lower stratosphere and sublimated in a subsaturated environment thereby hydrating the LS (the full processes are described at high temporal resolution in Dauhut et al., 2018). The $380 \mathrm{~K}$ potential temperature surface between $13.4^{\circ} \mathrm{S}$ and $13.6^{\circ} \mathrm{S}$ is smoother and returns to its initial altitude $(17 \mathrm{~km})$. The deformation of the $380 \mathrm{~K}$ surface between 12:05 UTC to 12:45 UTC suggests first strong deformation by the overshoot and then horizontal vertical propagation of high-frequency gravity waves triggered by deep convection. At 12:35 UTC, ice mixing ratio contours become more similar to their initial values in the LS. Ice, which previously sublimated, is diluted in the LS. At 12:45 UTC, vertical motion is very weak in the lower TTL and the $380 \mathrm{~K}$ isentropic surface has returned to its initial 11:55 UTC altitude. 
During the overshooting event on 4 March, the average LS water vapor mixing ratio increased from 6.1 to 7.4 ppmv around the TC center. It suggests transport of ice/water vapor from the troposphere. Ice sublimation in a sub-saturated LS leads to moistening. These results are further discussed in the discussion section.

\subsection{Water vapor in TTL}

We estimated the temporal change in TTL water vapor mixing ratio between the beginning and end of the MesoNH simulations. Water vapor profiles were averaged over a $500 \mathrm{~km}$ region surrounding Enawo on 2 March 06 UTC (6 hours after the start of the simulation) and 7 March 00 UTC (end of the simulation). The average water vapor mixing ratio difference between these two dates is shown on Figure 10 for the Meso-NH simulation. A minimum of water vapor hydration can be seen at $16.5 \mathrm{~km}$, near the tropical tropopause. A weak dehydration of 0.1 ppmv can be seen near the tropopause at $16.5 \mathrm{~km}$. Using CFH and MLS water vapor profiles, Evan et al. (2020) estimated dehydration ranging from -0.4 to $-0.1 \mathrm{ppmv}$ at $100 \mathrm{hPa}$ from a monthly mean MLS climatology (Figure 9 of Evan et al., 2020). Between 17 to $19 \mathrm{~km}$ an increase in water vapor mixing ratio up to 2 ppmv can be seen. Allison et al., 2018 reported hydration between 17.5 and $21 \mathrm{~km}$ associated with Hurricane Ingrid (Category 1) over the North Atlantic, with a maximum of 2.6 ppmv. Ice crystals were transported to the LS by deep convection, sublimated and produced hydration.

Figure 11 shows time versus distance from Enawo's center simulated lower stratospheric water vapor mixing ratio, averaged over the 17-19 km altitude range, from 2 March, 06 UTC to 6 March, 18 UTC. Enhanced mixing ratio of water vapor, $\sim 5$ to 6 ppmv compared to a background mi xing ratio of $3.3 \mathrm{ppmv}$, is observed first on March 3 at 00UTC near Enawo's center. High clouds were indeed observed on March 3, but as shown on Figure 5, the eyewall region in the simulation is not as well defined as in the observation and therefore this hydration event may be not well reproduced by the model. The enhanced mixing ratio has a slant wise propagation along time, with the enhanced mixing ratio propagating about $300 \mathrm{~km}$ away from Enawo's center in 12 hours. It shows that the water vapor injected near Enawo's center is advected outward from the storm's center, following the upper divergence wind pattern and Enawo's displacement, in the simulation.

A second hydration event near Enawo's center can be observed after 4 March 12 UTC. It is related to injection of ice in the TTL discussed in section 4.1 and 4.2 and depicted on Figure 8. The water vapor mixing ratio increased

410 up to 7 ppmv in a $100 \mathrm{~km}$ radius around Enawo's center. Then, as observed for the injection on 3 March, the water vapor positive anomaly propagates outward Enawo's center, with water vapor mixing ratio of 5 ppmv transported $500 \mathrm{~km}$ away from Enawo's storm after 1.5 day of transport. At the end of the simulation, the water vapor mixing ratio background rose from $3.3 \mathrm{ppmv}$ to $4.8 \mathrm{ppmv}$, an increase of 45\%, $500 \mathrm{~km}$ away from Enawo's center.

\section{Global impact of TCs to the tropical lower stratospheric water vapor}

415 We compute a net vertical water vapor flux $\mathrm{F}_{\text {mean }}\left(\mathrm{t} . \mathrm{hr}^{-1}\right.$, where $\mathrm{t}$ corresponds to the metric ton) at $18 \mathrm{~km}$ which corresponds to the lower-stratosphere using:

$$
F_{\text {mean }}=\sum_{i} \rho_{i} q_{v i} w_{i} \times A \times 3.6(2)
$$

Where $\rho$ is the density $\left(\mathrm{kg} \cdot \mathrm{m}^{-3}\right)$, w the vertical velocity $\left(\mathrm{m} \cdot \mathrm{s}^{-1}\right)$ at a grid point, qv the water vapor mixing ratio $\left(\mathrm{kg} \cdot \mathrm{kg}^{-1}\right)$ at a grid point, A is the area of a grid cell $\left(2000 \times 2000 \mathrm{~m}^{2}\right)$ and the 3.6 factor accounts for the conversion 
420 from kg.s. $\mathrm{s}^{-1}$ to t.hr-1. Net vertical water vapor flux was calculated by summing all flux values at individual grid points, regardless of sign, for a region of $700 \mathrm{~km}$ surrounding the TC center. It was found that a $\sim 700 \mathrm{~km}$ radius best encompassed Enawo's circulation. Allison et al., (2018) used a radius of $300 \mathrm{~km}$ to define TC Ingrid in the North Atlantic and Preston et al. (2019) used a radius of $900 \mathrm{~km}$ for Typhoon Mireille in the Western North Pacific. We use hourly outputs on 4 and 5 March 2017 (48 hours) to estimate net vertical water vapor flux as it corresponds to days with larger water vapor fluxes on Figure 8.

Figure 12 displays the evolution of net water vapor flux $F_{\text {mean }}$ at $18 \mathrm{~km}$ for 4-5 March 2017. The average net water vapor flux of $2.7 \times 10^{3} \mathrm{t}^{-\mathrm{hr}^{-1}}$ is positive, indicating that Enawo is a source of vapor for the lower stratosphere. The net water vapor flux varies from -1.3 to $1.7 \times 10^{4} \mathrm{t}^{-h^{-1}}$ with local peak values on 4 March 06 UTC, 5 March 06 UTC and 20 UTC (Enawo first achieved TC status on 5 March 12 UTC). Chaboureau et al. (2007) found observed peak water vapor flux of $2.8 \times 10^{4} \mathrm{t}^{\mathrm{hr}} \mathrm{r}^{-1}$ across the tropical $380 \mathrm{~K}$ level $(\sim 100 \mathrm{hPa})$ for a case of land-convection over Brazil. Allison et al. (2018) used high-resolution (1.33 km) numerical simulations of TC Ingrid (September 2013) in the North Atlantic to assess vertical water vapor transport to the lower stratosphere. The net water vapor flux at $100 \mathrm{hPa}$ was $2.1 \times 10^{3} \mathrm{t}^{-1}$ on 14 September 18 UTC when Ingrid first achieved hurricane status. Over a 43 hour period, net vertical flux values ranged from $-4.6 \times 10^{3}$ to $1.2 \times 10^{4} \mathrm{t}^{-\mathrm{hr}^{-1}}$. They estimated a total mass water vapor transport of $2 \times 10^{5} \mathrm{t}$ to the $100 \mathrm{hPa}$ level associated with Category $1 \mathrm{TC}$ Ingrid (thus an average net vapor flux of 4.6x10 $\mathrm{t}^{\mathrm{h}} \mathrm{hr}^{-1}$ ). Similarly, Preston et al. (2019) performed a $3 \mathrm{~km}$ explicit convection simulation of Typhoon Mireille (1991) over the Western North Pacific, and found a similar average net water vapor flux to Allison et al. (2018). TC Mireille and TC Enawo have a comparable intensity (maximum sustained winds of $51.4 \mathrm{~m} \mathrm{~s}-1$ and a central pressure of $925 \mathrm{hPa}$.) as category $3 \mathrm{TC}$, but Mireille was a larger system with a $900 \mathrm{~km}$ radius.

We can use our estimate of average net water vapor flux to the low stratosphere associated with Enawo to estimate the contribution to stratospheric water vapor from SWIO storms. Using the Best-Track data produced by RSMC La Réunion and focused on the most reliable 18-year period of the geostationary satellite era encompassing the 1999/2000-2016/17 cyclone seasons, we found an average of 4.8 TCs per year formed over the SWIO, in agreement with Leroux et al. (2018). We also estimated an average duration of $74 \pm 49$ hours ( \pm refers to the standard deviation) per cyclone. Using an average net water vapor flux of $2.7 \times 103$ t.hr-1 $^{-1}$ from Enawo's highresolution simulation, we estimate that TCs over the SWIO could transport 9.6x105 t of water vapor into the lower stratosphere. Figure 10 shows that Enawo moistened the region between $\sim 18$ and $20 \mathrm{~km}$. Dauhut et al. (2015) found moistening associated with a Hector thunderstorm between potential temperature levels $380-420 \mathrm{~K}(\sim 17-$ $18.5 \mathrm{~km}$ ). Using CALIOP data, Avery et al. (2017) reported that convective ice could be observed up to up to 2

$450 \mathrm{~km}$ above the tropopause over the Central Eastern Pacific (Figure 2a, 2b of Avery et al., 2017) due to the strong 2015-2016 El Niño. With a mean air density taken to be $0.1 \mathrm{~kg} . \mathrm{m}^{-3}$ between 18 and $20 \mathrm{~km}$, TCs over the SWIO $\left(0-30^{\circ} \mathrm{S}, 30-90^{\circ} \mathrm{E}\right)$ could produce a moistening of $0.4 \mathrm{ppmv}$, over a region which represents $\sim 8 \%$ of the global tropics $\left(30^{\circ} \mathrm{S}-30^{\circ} \mathrm{N}\right)$.

While an individual TC may not contribute much to stratospheric water vapor, collectively all TCs on the globe may have a larger impact. The global TC transport of water vapor to the stratosphere can be computed as:

Global TC mass of water vapor $(t)=F_{\text {mean }} \times \mathrm{NTC} \times$ DTC (3)

Fmean is the mean estimate of net water vapor flux at the tropopause $\left(\mathrm{t}^{\mathrm{h}} \mathrm{r}^{-1}\right)$ for an individual TC, NTC is the average global number of TCs and DTC is the mean duration of a TC (in hours). We can estimate that Fmean 
460 ranges from 2.7 to $4.6 \times 10^{3} \mathrm{t}^{\mathrm{h} r^{-1}}$ using the net water vapor flux estimates from Allison et al. (2018), Preston et al. (2019) and our simulation.

We derive NTC and DTC of tropical cyclones from the International Best Track Archive for Climate Stewardship (IBTrACS) (Knapp et al., 2010). IBTrACS is a composite dataset of track estimates for TCs, which combines data from multiple agencies to facilitate analysis. We specifically use data from version 4 for the period of global satellite coverage 1981-2017. The IBTrACS dataset defines 6 TC basins which are the North Atlantic, the West Pacific, the East Pacific, the South Pacific, the North Indian and the South Indian (Souwestern + Southeastern Indian Ocean). Agencies differ in their definition of maximum winds. Agencies in the United States use a 1 -min wind, RSMC New Delhi reports a 3-min wind but most RSMCs use a 10-min wind. To compare our results to previous estimates (WMO 2017 and Schreck et al., 2014), the IBTrACS 10-min maximum sustained winds from

470 RSMCs Tokyo, Fiji, Wellington, La Réunion, and the Australian Bureau of Meteorology are divided by 0.88 to approximate a 1-min wind (hereafter VMAX). The data from RSMCs Miami and New Delhi are used in their original form. For each of TC basin, we consider only systems that reach the TC stage (ie. VMAX $\geq 64 \mathrm{kt}$ ) and compute their mean duration as the period during which $\mathrm{VMAX} \geq 64 \mathrm{kt}$. We also consider VMAX at peak intensity. The results for individual basins and the global tropics are summarized in Table 3. Number of TCs shown in Table 3 can be compared to Table 2.5 of WMO (2017) and Table 3 of Schreck et al., (2014). The mean global NTC is $45 \pm 9$ for the period 1981-2010. On average, these systems have a DTC of $78 \pm 19$ hours. Using equation (3), we can estimate that TCs could contribute annually from 0.3 to $0.5 \mathrm{ppmv}$ to the tropical lower stratospheric water vapor.

Several uncertainties arise for the estimate of global TC transport of water vapor from equation (3). The annual

480 estimate of global TC water vapor transport has a combined uncertainty of $27 \%$ due to the NTCxDTC term in equation (3). But the largest uncertainty in equation (3) arises from the estimate of Fmean which in turn depends on TC structure/intensity and representation of microphysical as well as dynamical processes. It is difficult to assess the uncertainty due to the microphysical processes in the models (thus the uncertainty on water vapor mass mixing ratio and vertical velocity change due to latent heat release). In addition, Dauhut et al. (2017) discuss uncertainty in Fmean estimate due to an Eulerian versus Lagrangian approach. The Eulerian approach leads to larger estimates that can be attributed to reversible motions like gravity waves, which actually do not transport mass. Mrowiec et al. (2015) compare the Eulerian and isentropic computations of the vertical mass flux for a deep convective event around Darwin. The Eulerian computation based on a positive velocity threshold gives a 50\% larger estimate than the isentropic computation. Thus, the Eulerian approach used in Allison et al. (2018), Preston et al. (2019) and the present study could bias the Fmean flux estimate by up to $50 \%$.

\section{Discussion}

The global TC induced LS water vapor anomalies can be compared to previous studies that have quantified the impact of convection on tropical lower stratospheric water vapor.

Using Lagrangian trajectories driven by 6-hourly interim reanalysis of the ECMWF Forecast (ERA-Interim),

495 Ueyama et al. (2018) assess the impact of convection on the humidity and clouds in the TTL during boreal summer 2007. They estimated that convection moistens the 100 - hPa level by 0.6 ppmv averaged over the $10^{\circ} \mathrm{S}-50^{\circ} \mathrm{N}$ domain. $\sim 50 \%$ of this increase $(\sim 0.3 \mathrm{ppmv})$ is due to the effect of the Asian monsoon $\left(0-40^{\circ} \mathrm{N}, 40-140^{\circ} \mathrm{E}\right)$ convection. Nützel et al. (2019) performed a 4-year simulation with the chemistry-transport model Chemical 
Lagrangian Model of the Stratosphere (CLaMS) driven by the ERA-Interim data and established that water vapor stratosphere at $450 \mathrm{~K}(\sim 19 \mathrm{~km})$. The Asian monsoon region corresponds to an area roughly $13 \%$ of the tropics and is mainly active in July-August. Avery et al. (2017) used CALIOP observations of ice, MLS observations of water vapor and lagrangian trajectories to estimate large anomalies in lower stratospheric water vapor and ice during the 2015-2016 strong El Niño. A 0.9 ppmv tropical lower stratospheric moistening was observed during this event, with 0.5-0.6 ppmv due to anomalously warm Tropical Warm Pool tropopause temperatures during December 2015 and 0.3-0.4 ppmv due to deep convection over the Central Pacific ( $11 \%$ of the tropics). Therefore, our estimate of global TC tropical lower stratospheric moistening of 0.3 to 0.5 ppmv agrees with previous studies that have considered deep convection on a regional scale.

The Asian Monsoon in the Northern Hemisphere is clearly the most important source region but our analysis suggests that the most intense TCs may contribute to the tropical lower stratospheric water vapor budget, especially in the Southern Hemisphere where there is no similar monsoon circulation. Because climate models and observations predict more intense TC with warming sea surface temperatures (Elsner et al., 2008; Kossin et al., 2020; Sobel et al., 2016), accurate understanding of the stratospheric impact of TC convection is critical in the context of global warming. This is important not only for the lower stratospheric water vapor budget but also for

515 the transport of other chemical species (e.g. ozone, CO, ozone depleting substances) to the UTLS.

There are several limitations to the present study. First, we consider a single TC in the SWIO to assess the net TC water vapor transport to the stratosphere in the SWIO basin. TC Enawo may not be representative of other TCs in other basins as it was an intense TC (the strongest TC of the Southern Hemisphere for the 2016/2017 TC season). Then, large-eddy simulations may be needed to better resolve deep convection and associated convective updrafts, especially in the eyewall region. Heath et al. (2017) used $450 \mathrm{~m}$ WRF large-eddy simulations to study deep convection during a real-world case (a case of continental convection over Northern America on 2 September 2013) and concluded that moving from grid-spacing of $1.35 \mathrm{~km}$ to $450 \mathrm{~m}$ yielded results that better compared with ground-based radar and aircraft observations. Dauhut et al. (2015) found that a grid spacing on the order of $100 \mathrm{~m}$ may be necessary for a reliable estimate of hydration in a Meso-NH simulation of a Hector thunderstorm observed on 30 November 2005 over the Tiwi Islands. Large-eddy simulations of TC Enawo would be valuable, especially for convective updrafts in the eyewall region, but would require more computer power.

Finally, we use a single-moment microphysics scheme in our 2-km simulation of TC Enawo. One conclusion from Allison et al. (2016) for TC Ingrid is that double-moment microphysics schemes produce more realistic tropical clouds and precipitation, which are important for the representations of updrafts and transport of ice to the TTL.

530 While our comparison to the GPM satellite observations suggests that the simulation seems to reproduce well both location and amplitude of the observed precipitation, our comparison to CALIOP IWC indicates that ice above the tropopause is most likely overestimated in the simulation. Hoarau et al. (2018) performed a 2-km cloud resolving Meso-NH simulation of TC Dumile (10-min maximum sustained wind of $36 \mathrm{~m} . \mathrm{s}^{-1}$ or $70 \mathrm{kts}$ at peak intensity) using the ORILAM (Organic Inorganic Log-normal Aerosol Model; Tulet, 2005) aerosol scheme and

535 the LIMA (LIMA, Liquid Ice Multiple Aerosols; Vié et al., 2016) two-moment microphysics scheme. Using a one-moment microphysics scheme (ICE3, the scheme used in the present study) for the simulation of TC Dumile led to a larger, more symmetric and more intense system than using a two-moment microphysics scheme coupled with an aerosol scheme. It would be interesting to use the same aerosol-microphysics coupling for TC Enawo and 
assess the impact on the model's representation of TTL ice and water vapor transport to the UTLS, however the computation time is expected to increase by a factor 3. In addition, Jiang et al. (2019) investigated the effects of sea salt aerosols on precipitation and UTLS water vapor in TCs with the WRF model. They simulated typhoon Hato in the Northwestern Pacific using two nested domains with horizontal resolutions of $9 \mathrm{~km}$ and $3 \mathrm{~km}$. They performed two numerical experiments with the same two-moment microphysics scheme but different sea salt emission intensity. The experiment with increased sea salt emission intensity indicated an increase in precipitation as well as more intense vertical movement in the eyewall and thus more water vapor transport to the upper troposphere, which promoted cloud ice deposition. This experiment was drier in the UTLS (above $17 \mathrm{~km}$ ) and had a 18-20 km domain-averaged water vapor mixing ratio $\sim 0.02$ lower than the experiment with reduced sea salt emission. The enhanced air drying was explained by the enhancement of cloud ice deposition growth, which consumes more water vapor in the upper troposphere. The aerosol-microphysics schemes presented in Hoarau et al. (2018) can be used in an ocean-waves-atmosphere coupled system (Pianezze et al., 2018) to include the effects of sea-salt aerosols on the microphysical structure of tropical cyclone. It could also be interesting to use this version of Meso-NH to further investigate water vapor transport to the UTLS in TCs.

The large uncertainty in our estimate of net flux of water vapor requires additional modeling (convectionpermitting) and analysis of TTL in-situ/satellite observations of TCs in various basins but this is left to further

555 study. A preliminary analysis of 17-years MLS observations of water vapor for the most intense TCs (categories $4 \& 5$ on the Saffir-Simpson Scale) over 3 TC basins (Western North Pacific, North Atlantic and Soutwestern Indian Ocean) show that these storms moisten the lower stratosphere $(83 \mathrm{hPa} / \sim 18 \mathrm{~km})$ from 0.3 to $0.5 \mathrm{ppmv}$ in a $\sim 5$ to $10^{\circ}$ region around the eye.

\section{Summary and Conclusions}

560 We extended the analysis of Evan et al. (2020) on the impact of TC Enawo on the TTL water vapor using the Meso-NH cloud resolving Mesoscale model. Between 2 and 4 March, Enawo intensified from TD to TS. On 4 March, Enawo stalled over the ocean while intensifying. Enawo evolved from TS to TC on 5 March, and reached peak intensity on 7 March.

The Meso-NH high-resolution (2 km) simulation used in this study covers Enawo's lifecycle from 2 to 7 March

565 for a model domain covering the SWIO. Five configurations were used to test the sensitivity of the model to domain extent, horizontal resolution, and SST boundary conditions.

The westward propagation of Enawo was relatively well represented by the model simulations with comparable propagation speed to the best track, and a maximum deviation between the simulated and observed tracks of $\sim 100 \mathrm{~km}$. All the simulations were able to show that Enawo stalled over the ocean while intensifying on 4 March.

570 Overall, simulation S4 achieved the most realistic representation of Enawo's intensity and propagation. Precipitations in simulation S4 were compared to GPM satellite observed rainfall. Precipitation in the eyewall tends to be overestimated in simulation S4, while precipitation within the secondary rainbands were consistent with those observed by GPM. Infrared brightness temperatures in simulation S4 were compared to the METEOSAT 8 satellite images. The horizontal structure of the cloud tops within Enawo is relatively well

575 represented. Simulation S4 had slightly higher convective clouds, as simulated convective clouds were $2^{\circ} \mathrm{C}$ colder than the observed ones. 
Profiles of IWC in simulation S4 were compared through a vertical cross section of a CALIPSO overpass over the eyewall on 5 March 21:30 UTC. Observed and simulated IWC have similar ranges in the upper troposphere but simulated ice above the tropopause is overestimated by a factor 10 . The location of the convective center was fairly well reproduced by the simulation, but the distribution ice above the CPT in simulation S4 covers a larger region than in CALIPSO.

Net mass fluxes of water vapor and ice into the stratosphere were estimated within a $700 \mathrm{~km}$ region around Enawo's center. Injection of water vapor and ice was maximum during the intensification phase of Enawo, when it stalled over the ocean on 4 March. Injection of ice decreased after March 5, although Enawo reached its peak intensity on 7 March

An overshooting convection event on 4 March was analysed in detail. Direct injection of ice was simulated between 17 and $19 \mathrm{~km}$ altitude, associated with dehydration below the tropopause. Ice between 17 and $19 \mathrm{~km}$ altitude sublimated in a subsaturated environment and thereby hydrated the low er stratosphere. On average, the overshooting event simulated on 4 March 12UTC increased the lower stratospheric water vapor mixing ratio by

$5901.3 \mathrm{ppmv}$ in a $50 \mathrm{~km}$ region around the TC center.

Water vapor profiles simulated by the $2 \mathrm{~km}$ Meso-NH simulations were averaged over a $500 \mathrm{~km}$ region surrounding Enawo's center. A negative water vapor change of -0.1 ppmv was found at $16.5 \mathrm{~km}$ altitude near the tropical tropopause. Between 17 and $19 \mathrm{~km}$ in altitude, an increase of $\sim 2$ ppmv in water vapor mixing ratio was simulated.

595 Comparison of net mass flux of water vapor and ice indicated that positive net mass fluxes of water vapor into the stratosphere are not necessarily associated with direct injection of ice by overshooting convection. The positive anomaly in the lower stratosphere started from the eye region of the storm and propagated outward Enawo's center. At the end of the simulation, the water vapor mixing ratio background rose by $1.5 \mathrm{ppmv}$, an increase of $45 \%, 500 \mathrm{~km}$ away from Enawo's center.

600 Our simulation of TC Enawo suggests that TCs over the SWIO $\left(0-30^{\circ} \mathrm{S}, 30-90^{\circ} \mathrm{E}\right)$ could produce a moistening of 0.4 ppmv over a region which represents $\sim 8 \%$ of the global tropics $\left(30^{\circ} \mathrm{S}-30^{\circ} \mathrm{N}\right)$. We extended our results to estimate the global impact of TCs to the tropical lower stratospheric water vapor using the estimates from published work (Allison et al., 2018; Preston et al., 2019) and by calculating statistics on TC numbers and durations using the IBTrACS dataset. We estimated a global impact of TC induced tropical lower stratospheric moistening of 0.3 to $0.5 \mathrm{ppmv}$.

Data availability. METEOSAT 8 data are accessible at https://disc.gsfc.nasa.gov/datasets/ 371 GPM MERGIR 1/summary. The GPM are provided by G. Huffman, D. Bolvin, D. Braithwaite, K. Hsu, R. Joyce, P. Xie, 2014: Integrated Multi-satellitE Retrievals for GPM (IMERG), version 4.4. NASA's Precipitation Processing Center, accessed 29 September, 2020, ftp://arthurhou.pps.eosdis.nasa.gov/gpmdata/. V4.10 CALIPSO Level $25 \mathrm{~km}$

610 cloud layer product is available at: https://doi.org/10.5067/CALIOP/CALIPSO/LID L2 05KMCLAYSTANDARD-V4-10. The IBTrACS data are provided by Knapp, Kenneth R.; Diamond, Howard J.; Kossin, James P.; Kruk, Michael C.; Schreck, Carl J. III (2018). International Best Track Archive for Climate Stewardship (IBTrACS) Project, Version 4. NOAA National Centers for Environmental Information. https://doi.org/10.25921/82ty-9e16. The CFH water vapor data is available from the SE upon request.

615 Author contributions. All authors contributed to the paper. DH and SE wrote the manuscript with contributions from JP, TD, JB, KR, VN, SB, CB and JPC. DH performed the Meso-NH simulations. All authors revised the manuscript draft.

Competing interests. The authors declare that they have no conflict of interest. 
Acknowledgments

620 This work was partly funded by the French LEFE CNRS-INSU Program (VAPEURDO) and by the French Agence Nationale de la Recherche CONCIRTO project (ANR375 17-CE01-0005-01). Computer resources were allocated by GENCI (project 1100297). The Meso-NH code is publicly available at http://www.mesonh.aero.obs-

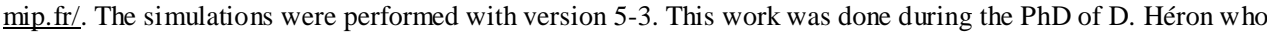
was financially supported by a MENRT fellowship from the University of Réunion Island.

\section{References}

Allison, T.: WRF simulations of water vapor content for TC Ingrid (September 2013). M. S. Thesis. Florida State University, College of Art and Sciences. Tallahassee, Florida. 2016.

Allison, T., Fuelberg, H. and Heath, N.: Simulations of Vertical Water Vapor Transport for TC Ingrid (2013), Journal of Geophysical Research: Atmospheres, 123(15), 8255-8282, doi:10.1029/2018JD028334, 2018.

630 Avery, M., Winker, D., Heymsfield, A., Vaughan, M., Young, S., Hu, Y. and Trepte, C.: Cloud ice water content retrieved from the CALIOP space-based lidar: CALIOP ICE WATER CONTENT, Geophys. Res. Lett., 39(5), n/a-n/a, doi:10.1029/2011GL050545, 2012.

Avery, M. A., Davis, S. M., Rosenlof, K. H., Ye, H. and Dessler, A. E.: Large anomalies in lower stratospheric water vapour and ice during the 2015-2016 El Niño, Nature Geosci, 10(6), 405-409, doi:10.1038/ngeo2961,

6352017

Barbary, D., Leroux, M. and Bousquet, O.: The orographic effect of Reunion Island on tropical cyclone track and intensity, Atmos Sci Lett, 20(2), e882, doi:10.1002/asl.882, 2019.

Bergman, J. W., Jensen, E. J., Pfister, L. and Yang, Q.: Seasonal differences of vertical-transport efficiency in the tropical tropopause layer: On the interplay between tropical deep convection, large-scale vertical ascent, and

640 horizontal circulations: VERTICAL-TRANSPORT EFFICIENCY IN THE TTL, J. Geophys. Res., 117(D5), n/an/a, doi:10.1029/2011JD016992, 2012.

Brewer, A. W.: Evidence for a world circulation provided by the measurements of helium and water vapour distribution in the stratosphere, Q.J Royal Met. Soc., 75(326), 351-363, doi:10.1002/qj.49707532603, 1949.

Chaboureau, J.-P., Cammas, J.-P., Duron, J., Mascart, P. J., Sitnikov, N. M. and Voessing, H.-J.: A numerical 645 study of tropical cross-tropopause transport by convective overshoots, Atmospheric Chemistry and Physics, 7(7), 1731-1740, doi:https://doi.org/10.5194/acp-7-1731-2007, 2007.

Chandrasekar, R. and Balaji, C.: Sensitivity of tropical cyclone Jal simulations to physics parameterizations, J Earth Syst Sci, 121(4), 923-946, doi:10.1007/s12040-012-0212-8, 2012.

Corti, T., Luo, B. P., de Reus, M., Brunner, D., Cairo, F., Mahoney, M. J., Martucci, G., Matthey, R., Mitev, V., 650 dos Santos, F. H., Schiller, C., Shur, G., Sitnikov, N. M., Spelten, N., Vössing, H. J., Borrmann, S. and Peter, T.: Unprecedented evidence for deep convection hydrating the tropical stratosphere: CONVECTIVE HYDRATION, Geophys. Res. Lett., 35(10), doi:10.1029/2008GL033641, 2008.

Cuxart, J., Bougeault, P. and Redelsperger, J.-L.: A turbulence scheme allowing for mesoscale and large-eddy simulations, Q.J Royal Met. Soc., 126(562), 1-30, doi:10.1002/qj.49712656202, 2000.

655 Dauhut, T., Chaboureau, J.-P., Escobar, J. and Mascart, P.: Large-eddy simulations of Hector the convector making the stratosphere wetter, Atmospheric Science Letters, 16(2), 135-140, doi:10.1002/asl2.534, 2015.

Dauhut, T., Chaboureau, J.-P., Escobar, J. and Mascart, P.: Giga-LES of Hector the Convector and Its Two Tallest Updrafts up to the Stratosphere, J. Atmos. Sci., 73(12), 5041-5060, doi:10.1175/JAS-D-16-0083.1, 2016. 
Dauhut, T., Chaboureau, J.-P., Haynes, P. H. and Lane, T. P.: The Mechanisms Leading to a Stratospheric doi:10.1175/JAS-D-18-0176.1, 2018.

Debreu, L., Marchesiello, P., Penven, P. and Cambon, G.: Two-way nesting in split-explicit ocean models: Algorithms, implementation and validation, Ocean Modelling, 49-50, 1-21, doi:10.1016/j.ocemod.2012.03.003, 2012.

665 Dessler, A. E., Ye, H., Wang, T., Schoeberl, M. R., Oman, L. D., Douglass, A. R., Butler, A. H., Rosenlof, K. H., Davis, S. M. and Portmann, R. W.: Transport of ice into the stratosphere and the humidification of the stratosphere over the 21st century: TWENTY-FIRST CENTURY STRATOSPHERIC WATER TREND, Geophys. Res. Lett., 43(5), 2323-2329, doi:10.1002/2016GL067991, 2016.

Elsner, J. B., Kossin, J. P. and Jagger, T. H.: The increasing intensity of the strongest tropical cyclones, Nature, 455(7209), 92-95, doi:10.1038/nature07234, 2008.

Evan, S., Brioude, J., Rosenlof, K., Davis, S. M., Vömel, H., Héron, D., Posny, F., Metzger, J.-M., Duflot, V., Payen, G., Vérèmes, H., Keckhut, P. and Cammas, J.-P.: Effect of deep convection on the TTL composition over the Southwest Indian Ocean during austral summer, Atmospheric Chemistry and Physics Discussions, 1-44, doi:https://doi.org/10.5194/acp-2019-1072, 2020.

675 Fairall, C. W., Bradley, E. F., Hare, J. E., Grachev, A. A. and Edson, J. B.: Bulk Parameterization of Air-Sea Fluxes: Updates and Verification for the COARE Algorithm, JOURNAL OF CLIMATE, 16, 21, 2003.

Foucart, Y. and Bonnel, B.: COMPUTATIONS OF SOLAR HEATING OF THE EARTH'S ATMOSPHERE: A NEW PARAMETERIZATION, BEITR. PHYS. ATMOSPH.; DEU; DA. 1980; VOL. 53; NO 1; PP. 35-62; ABS. GER/FRE; BIBL. 2 P., 1980.

680 Frey, W., Schofield, R., Hoor, P., Kunkel, D., Ravegnani, F., Ulanovsky, A., Viciani, S., D’Amato, F. and Lane, T. P.: The impact of overshooting deep convection on local transport and mixing in the tropical upper troposphere/lower stratosphere (UTLS), Atmospheric Chemistry and Physics, 15(11), 6467-6486, doi:https://doi.org/10.5194/acp-15-6467-2015, 2015.

Fueglistaler, S., Dessler, A. E., Dunkerton, T. J., Folkins, I., Fu, Q. and Mote, P. W.: Tropical tropopause layer, 685 Reviews of Geophysics, 47(1), doi:10.1029/2008RG000267, 2009.

Hassim, M. E. E. and Lane, T. P.: A model study on the influence of overshooting convection on TTL water vapour, Atmos. Chem. Phys., 10(20), 9833-9849, doi:10.5194/acp-10-9833-2010, 2010.

Heath, N. K., Fuelberg, H. E., Tanelli, S., Turk, F. J., Lawson, R. P., Woods, S. and Freeman, S.: WRF nested large-eddy simulations of deep convection during SEAC ${ }^{4}$ RS: NESTED LES OF DEEP CONVECTION, J.

690 Geophys. Res. Atmos., 122(7), 3953-3974, doi:10.1002/2016JD025465, 2017.

Hoarau, T., Barthe, C., Tulet, P., Claeys, M., Pinty, J.-P., Bousquet, O., Delanoë, J. and Vié, B.: Impact of the Generation and Activation of Sea Salt Aerosols on the Evolution of Tropical Cyclone Dumile, J. Geophys. Res. Atmos., 123(16), 8813-8831, doi:10.1029/2017JD028125, 2018.

Huffman George J., David T. Bolvin, Dan Braithwaite, Kuolin Hsu, Robert Joyce, Christopher Kidd, Eric J.

695 Nelkin,Soroosh Sorooshian, Jackson Tan,Pingping Xie. 'NASA Global Precipitation Measurement (GPM) Integrated Multi-satellitE Retrievals for GPM (IMERG)'. Available at https://docserver.gesdisc.eosdis.nasa.gov/public/project/GPM/IMERG_ATBD_V06.pdf

Jensen, E. J., Ackerman, A. S. and Smith, J. A.: Can overshooting convection dehydrate the tropical tropopause layer?, J. Geophys. Res., 112(D11), D11209, doi:10.1029/2006JD007943, 2007.

700 Jensen, E. J., Diskin, G., Lawson, R. P., Lance, S., Bui, T. P., Hlavka, D., McGill, M., Pfister, L., Toon, O. B. and Gao, R.: Ice nucleation and dehydration in the Tropical Tropopause Layer, Proceedings of the National Academy of Sciences, 110(6), 2041-2046, doi:10.1073/pnas.1217104110, 2013. 
Jiang, B., Wang, D., Shen, X., Chen, J. and Lin, W.: Effects of sea salt aerosols on precipitation and upper troposphere/lower stratosphere water vapour in tropical cyclone systems, Sci Rep, 9(1), 15105, doi:10.1038/s41598-019-51757-x, 2019.

John Janowiak, B. J.: NCEP/CPC L3 Half Hourly 4km Global (60S - 60N) Merged IR V1, , doi:10.5067/P4HZB9N27EKU, 2017.

Knapp, K. R., Kruk, M. C., Levinson, D. H., Diamond, H. J. and Neumann, C. J.: The International Best Track Archive for Climate Stewardship (IBTrACS): Unifying Tropical Cyclone Data, Bull. Amer. Meteor. Soc., 91(3), 710 363-376, doi:10.1175/2009BAMS2755.1, 2010

Kossin, J. P., Knapp, K. R., Olander, T. L. and Velden, C. S.: Global increase in major tropical cyclone exceedance probability over the past four decades, Proc Natl Acad Sci USA, 117(22), 11975-11980, doi:10.1073/pnas.1920849117, 2020.

Lac, C., Chaboureau, J.-P., Masson, V., Pinty, J.-P., Tulet, P., Escobar, J., Leriche, M., Barthe, C., Aouizerats, B.,

715 Augros, C., Aumond, P., Auguste, F., Bechtold, P., Berthet, S., Bielli, S., Bosseur, F., Caumont, O., Cohard, J.M., Colin, J., Couvreux, F., Cuxart, J., Delautier, G., Dauhut, T., Ducrocq, V., Filippi, J.-B., Gazen, D., Geoffroy, O., Gheusi, F., Honnert, R., Lafore, J.-P., Lebeaupin Brossier, C., Libois, Q., Lunet, T., Mari, C., Maric, T., Mascart, P., Mogé, M., Molinié, G., Nuissier, O., Pantillon, F., Peyrillé, P., Pergaud, J., Perraud, E., Pianezze, J., Redelsperger, J.-L., Ricard, D., Richard, E., Riette, S., Rodier, Q., Schoetter, R., Seyfried, L., Stein, J., S uhre, K.,

720 Taufour, M., Thouron, O., Turner, S., Verrelle, A., Vié, B., Visentin, F., Vionnet, V. and Wautelet, P.: Overview of the Meso-NH model version 5.4 and its applications, Geosci. Model Dev., 11(5), 1929-1969, doi:10.5194/gmd11-1929-2018, 2018.

Leroux, M.-D., Meister, J., Mekies, D., Dorla, A.-L. and Caroff, P.: A Climatology of Southwest Indian Ocean Tropical Systems: Their Number, Tracks, Impacts, Sizes, Empirical Maximum Potential Intensity, and Intensity

725 Changes, Journal of Applied Meteorology and Climatology, 57(4), 1021-1041, doi:10.1175/JAMC-D-17-0094.1, 2018.

Li, D., Vogel, B., Bian, J., Müller, R., Pan, L. L., Günther, G., Bai, Z., Li, Q., Zhang, J., Fan, Q. and Vömel, H.: Impact of typhoons on the composition of the upper troposphere within the Asian summer monsoon anticyclone: the SWOP campaign in Lhasa 2013, Atmos. Chem. Phys., 17(7), 4657-4672, doi:10.5194/acp-17-4657-2017, 2017.

Marécal, V., Rivière, E. D., Held, G., Cautenet, S. and Freitas, S.: Modelling study of the impact of deep convection on the utls air composition - Part I: Analysis of ozone precursors, Atmos. Chem. Phys., 6(6), 15671584, doi:10.5194/acp-6-1567-2006, 2006

Masson, V., Le Moigne, P., Martin, E., Faroux, S., Alias, A., Alkama, R., Belamari, S., Barbu, A., Boone, A., 735 Bouyssel, F., Brousseau, P., Brun, E., Calvet, J.-C., Carrer, D., Decharme, B., Delire, C., Donier, S., Essaouini, K., Gibelin, A.-L., Giordani, H., Habets, F., Jidane, M., Kerdraon, G., Kourzeneva, E., Lafaysse, M., Lafont, S., Lebeaupin Brossier, C., Lemonsu, A., Mahfouf, J.-F., Marguinaud, P., Mokhtari, M., Morin, S., Pigeon, G., Salgado, R., Seity, Y., Taillefer, F., Tanguy, G., Tulet, P., Vincendon, B., Vionnet, V. and Voldoire, A.: The SURFEXv7.2 land and ocean surface platform for coupled or offline simulation of earth surface variables and

740 fluxes, Geosci. Model Dev., 6(4), 929-960, doi:10.5194/gmd-6-929-2013, 2013.

Mlawer, E. J., Taubman, S. J., Brown, P. D., Iacono, M. J. and Clough, S. A.: Radiative transfer for inhomogeneous atmospheres: RRTM, a validated correlated-k model for the longwave, J. Geophys. Res., 102(D14), 16663-16682, doi:10.1029/97JD00237, 1997.

Mote, P. W., Rosenlof, K. H., McIntyre, M. E., Carr, E. S., Gille, J. C., Holton, J. R., Kinnersley, J. S., Pumphrey, 745 H. C., Russell, J. M. and Waters, J. W.: An atmospheric tape recorder: The imprint of tropical tropopause temperatures on stratospheric water vapor, J. Geophys. Res., 101(D2), 3989-4006, doi:10.1029/95JD03422, 1996.

Mrowiec, A. A., Rio, C., Fridlind, A. M., Ackerman, A. S., Del Genio, A. D., Pauluis, O. M., Varble, A. C. and Fan, J.: Analysis of cloud-resolving simulations of a tropical mesoscale convective system observed during TWP- 
ICE: Vertical fluxes and draft properties in convective and stratiform regions, Journal of Geophysical Research:

Nützel, M., Podglajen, A., Garny, H. and Ploeger, F.: Quantification of water vapour transport from the Asian monsoon to the stratosphere, Atmos. Chem. Phys., 19(13), 8947-8966, doi:10.5194/acp-19-8947-2019, 2019.

Penven, P., Debreu, L., Marchesiello, P. and McWilliams, J. C.: Evaluation and application of the ROMS 1-way embedding procedure to the central california upwelling system, Ocean Modelling, 12(1-2), 157-187, doi:10.1016/j.ocemod.2005.05.002, 2006.

Pergaud, J., Masson, V., Malardel, S. and Couvreux, F.: A Parameterization of Dry Thermals and Shallow Cumuli for Mesoscale Numerical Weather Prediction, Boundary-Layer Meteorol, 132(1), 83-106, doi:10.1007/s10546009-9388-0, 2009.

Pianezze, J., Barthe, C., Bielli, S., Tulet, P., Jullien, S., Cambon, G., Bousquet, O., Claeys, M. and Cordier, E.: A 760 New Coupled Ocean-Waves-Atmosphere Model Designed for Tropical Storm Studies: Example of Tropical Cyclone Bejisa (2013-2014) in the South-West Indian Ocean, J. Adv. Model. Earth Syst., 10(3), 801-825, doi:10.1002/2017MS001177, 2018.

Preston, A. D., Fuelberg, H. E. and Barth, M. C.: Simulation of Chemical Transport by Typhoon Mireille (1991), J. Geophys. Res. Atmos., 124(21), 11614-11639, doi:10.1029/2019JD030446, 2019.

765 Randel, W. J., Wu, F., Oltmans, S. J., Rosenlof, K. and Nedoluha, G. E.: Interannual Changes of Stratospheric Water Vapor and Correlations with Tropical Tropopause Temperatures, JOURNAL OF THE ATMOSPHERIC SCIENCES, 61, 16, 2004.

Ravindra Babu, S., Venkat Ratnam, M., Basha, G., Krishnamurthy, B. V. and Venkateswararao, B.: Effect of tropical cyclones on the tropical tropopause parameters observed using COSMIC GPS RO data, Atmos. Chem. Phys., 15(18), 10239-10249, doi:10.5194/acp-15-10239-2015, 2015.

Ray, E. A. and Rosenlof, K. H.: Hydration of the upper troposphere by tropical cyclones, Journal of Geophysical Research: Atmospheres, 112(D12), doi:10.1029/2006JD008009, 2007.

Romps, D. M. and Kuang, Z:: Overshooting convection in tropical cyclones, Geophys. Res. Lett., 36(9), L09804, doi:10.1029/2009GL037396, 2009.

775 Rosenlof, K. H., Oltmans, S. J., Kley, D., Russell, J. M., Chiou, E.-W., Chu, W. P., Johnson, D. G., Kelly, K. K., Michelsen, H. A., Nedoluha, G. E., Remsberg, E. E., Toon, G. C. and McCormick, M. P.: Stratospheric water vapor increases over the past half-century, Geophysical Research Letters, 28(7), 1195-1198, doi:10.1029/2000GL012502, 2001.

Saunders, R., Hocking, J., Turner, E., Rayer, P., Rundle, D., Brunel, P., Vidot, J., Roquet, P., Matricardi, M.,

780 Geer, A., Bormann, N. and Lupu, C.: An update on the RTTOV fast radiative transfer model (currently at version 12), Geosci. Model Dev., 11(7), 2717-2737, doi:10.5194/gmd-11-2717-2018, 2018.

Schoeberl, M. R., Jensen, E. J., Pfister, L., Ueyama, R., Avery, M. and Dessler, A. E.: Convective Hydration of the Upper Troposphere and Lower Stratosphere, J. Geophys. Res. Atmos., 123(9), 4583-4593, doi:10.1029/2018JD028286, 2018.

785 Schreck, C. J., Knapp, K. R. and Kossin, J. P.: The Impact of Best Track Discrepancies on Global Tropical Cyclone Climatologies using IBTrACS, Monthly Weather Review, 142(10), 3881-3899, doi:10.1175/MWR-D14-00021.1, 2014.

Senf, F. and Deneke, H.: Uncertainties in synthetic Meteosat SEVIRI infrared brightness temperatures in the presence of cirrus clouds and implications for evaluation of cloud microphysics, Atmospheric Research, 183, 113129, doi:10.1016/j.atmosres.2016.08.012, 2017. 
Shepherd, T. G.: Dynamics, stratospheric ozone, and climate change, Atmosphere-Ocean, 46(1), 117-138, doi:10.3137/ao.460106, 2008.

Sobel, A. H., Camargo, S. J., Hall, T. M., Lee, C.-Y., Tippett, M. K. and Wing, A. A.: Human influence on tropical cyclone intensity, Science, 353(6296), 242-246, doi:10.1126/science.aaf6574, 2016.

Solomon, S., Rosenlof, K. H., Portmann, R. W., Daniel, J. S., Davis, S. M., Sanford, T. J. and Plattner, G.-K.: Contributions of Stratospheric Water Vapor to Decadal Changes in the Rate of Global Warming, Science, 327(5970), 1219-1223, doi:10.1126/science.1182488, 2010.

Tao, C. and Jiang, H.: Global Distribution of Hot Towers in Tropical Cyclones Based on 11-Yr TRMM Data, J. Climate, 26(4), 1371-1386, doi:10.1175/JCLI-D-12-00291.1, 2013.

le Texier, H., Solomon, S. and Garcia, R. R.: The role of molecular hydrogen and methane oxidation in the water vapour budget of the stratosphere, Q.J Royal Met. Soc., 114(480), 281-295, doi:10.1002/qj.49711448002, 1988.

Tulet, P.: ORILAM, a three-moment lognormal aerosol scheme for mesoscale atmospheric model: Online coupling into the Meso-NH-C model and validation on the Escompte campaign, J. Geophys. Res., 110(D18), D18201, doi:10.1029/2004JD005716, 2005.

805 Ueyama, R., Jensen, E. J. and Pfister, L.: Convective Influence on the Humidity and Clouds in the Tropical Tropopause Layer During Boreal Summer, J. Geophys. Res. Atmos., doi:10.1029/2018JD028674, 2018.

Vié, B., Pinty, J.-P., Berthet, S. and Leriche, M.: LIMA (v1.0): A quasi two-moment microphysical scheme driven by a multimodal population of cloud condensation and ice freezing nuclei, Geosci. Model Dev., 9(2), 567-586, doi:10.5194/gmd-9-567-2016, 2016.

810 Vogel, B., Günther, G., Müller, R., Grooß, J.-U., Hoor, P., Krämer, M., Müller, S., Zahn, A. and Riese, M.: Fast transport from Southeast Asia boundary layer sources to northern Europe: rapid uplift in typhoons and eastward eddy shedding of the Asian monsoon anticyclone, Atmos. Chem. Phys., 14(23), 12745-12762, doi:10.5194/acp14-12745-2014, 2014.

Voldoire, A., Decharme, B., Pianezze, J., Lebeaupin Brossier, C., Sevault, F., Seyfried, L., Garnier, V., Bielli, S., 815 Valcke, S., Alias, A., Accensi, M., Ardhuin, F., Bouin, M.-N., Ducrocq, V., Faroux, S., Giordani, H., Léger, F., Marsaleix, P., Rainaud, R., Redelsperger, J.-L., Richard, E. and Riette, S.: SURFEX v8.0 interface with OASIS3MCT to couple atmosphere with hydrology, ocean, waves and sea-ice models, from coastal to global scales, Geosci. Model Dev., 10(11), 4207-4227, doi:10.5194/gmd-10-4207-2017, 2017.

Vömel, H., Barnes, J. E., Forno, R. N., Fujiwara, M., Hasebe, F., Iwasaki, S., Kivi, R., Komala, N., Kyrö, E., 820 Leblanc, T., Morel, B., Ogino, S.-Y., Read, W. G., Ryan, S. C., Saraspriya, S., Selkirk, H., Shiotani, M., Valverde Canossa, J. and Whiteman, D. N.: Validation of Aura Microwave Limb Sounder water vapor by balloon-borne Cryogenic Frost point Hygrometer measurements, J. Geophys. Res., 112(D24), D24S37, doi:10.1029/2007JD008698, 2007.

Vömel, H., Naebert, T., Dirksen, R. and Sommer, M.: An update on the uncertainties of water vapor measurements 825 using cryogenicfrost point hygrometers, Atmos. Meas. Tech., 9(8), 3755-3768, doi:10.5194/amt-9-3755-2016, 2016.

Wei, M.-Y.: A New Formulation of the Exchange of Mass and Trace Constituents between the Stratosphere and Troposphere, J. Atmos. Sci., (44), 3079-3086, 1987.

WMO: Global guide to tropical cyclone forecasting. C. Guard, Ed. WMO Tech. Rep. WMO/TD-1194, 399 pp.,

830 http://www.wmo.int/cycloneguide/pdf/Global-Guide-to-Tropical-Cyclone-Forecasting.pdf, 2017.

Zhan, R. and Wang, Y.: Contribution of tropical cyclones to stratosphere-troposphere exchange over the northwest Pacific: Estimation based on AIRS satellite retrievals and ERA-Interim data: CONTRIBUTION BY TCS TO STE OVER WNP, J. Geophys. Res., 117(D12), n/a-n/a, doi:10.1029/2012JD017494, 2012. 
Table 1: Definitions of Meso-NH simulations used in the study. All simulations are from 2 March 00UTC to 7 March 00 UTC just before Enawo's landfall over Madagascar. Root Mean Square Error (RMSE) between the Best Track and simulated values of track (in $\mathrm{km}$ ) and MSLP (in hPa) are calculated for each simulation. The values in brackets represent the standard deviation.

\begin{tabular}{|c|c|c|c|c|c|c|}
\hline $\begin{array}{c}\text { Simulatio } \\
\text { n name }\end{array}$ & $\begin{array}{c}\text { Horizontal } \\
\text { grid- } \\
\text { spacing } \\
(\mathrm{km})\end{array}$ & $\begin{array}{c}\text { Model } \\
\text { domain }\end{array}$ & $\begin{array}{c}\text { Interactive } \\
\text { SST }\end{array}$ & $\begin{array}{c}\text { Initial and } \\
\text { boundary } \\
\text { conditions }\end{array}$ & $\begin{array}{c}\text { Track } \\
\text { RMSE } \\
(\mathrm{km})\end{array}$ & $\begin{array}{c}\text { MSLP } \\
\text { RMSE } \\
(\mathrm{hPa})\end{array}$ \\
\hline S1 & 10 & A & Forced (IFS) & ECMWF IFS & $167 \pm 68$ & $7.4 \pm 5.8$ \\
\hline S2 & 5 & A & Forced (IFS) & ECMWF IFS & $141 \pm 67$ & $8.0 \pm 7.1$ \\
\hline S3 & 2 & A\&B & Forced (IFS) & ECMWF IFS & $105 \pm 50$ & $6.2 \pm 5.5$ \\
\hline S4 & 2 & B & Forced (IFS) & ECMWF IFS & $97 \pm 54$ & $5.7 \pm 5.1$ \\
\hline S5 & 2 & B & $\begin{array}{c}\text { Coupled } \\
\text { (CROCO) }\end{array}$ & ECMWF IFS & $87 \pm 48$ & $8.9 \pm 8.7$ \\
\hline
\end{tabular}

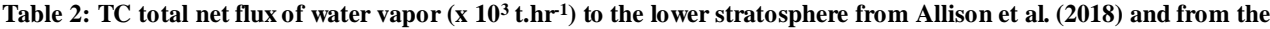
present study.

\begin{tabular}{|c|c|c|}
\hline & Note & $\mathrm{F}_{\text {mean }}\left(\mathrm{x} 10^{3} \mathrm{t}_{\mathrm{h}} \mathrm{hr}^{-1}\right)$ \\
\hline Allison et al. (2018) & $\begin{array}{c}\text { 300-km Cat 1 TC Ingrid in the NA } \\
1.33 \mathrm{~km} \text { grid-spacing, net flux estimated over 43 hours }\end{array}$ & 4.6 \\
\hline The present study & $\begin{array}{c}\text { 600-km Cat 3 TC Enawo in the SWIO } \\
2 \mathrm{~km} \text { grid-spacing, net flux estimated over 48 hours }\end{array}$ & 2.7 \\
\hline
\end{tabular}

Table 3: The 25th, mean (standard deviation), and 75th percentiles for each region and global tropics of the annual number of tropical cyclones with 1-min VMAX $\geq 64 \mathrm{kt}$. The 25th, mean (standard deviation), and 75th percentiles for each region and global tropics of the duration of tropical cyclones (hours). The duration of a TC is defined as the period during which VMAX $\geq 64 \mathrm{kt}$. The $25 \mathrm{th}$, mean (standard deviation), and 75th percentiles for each region and global tropics of maximum 1-min sustained wind (kt) at peak intensity.

\begin{tabular}{|c|c|c|c|c|c|c|c|c|c|}
\hline \multirow{2}{*}{ Region } & \multicolumn{3}{|c|}{$\begin{array}{c}\text { Number of TC } \\
(1-\min \text { VMAX } \geq 64 \mathrm{kt})\end{array}$} & \multicolumn{3}{|c|}{ Duration (hours) } & \multicolumn{3}{|c|}{$\begin{array}{l}\text { 1-min VMAX }(\mathrm{kt}) \text { at peak } \\
\text { intensity }\end{array}$} \\
\hline & $25^{\text {th }}$ & Mean & $75^{\text {th }}$ & $25^{\text {th }}$ & Mean & $7^{\text {th }}$ & $25^{\text {th }}$ & Mean & $75^{\text {th }}$ \\
\hline $\begin{array}{l}\text { Western } \\
\text { Pacific }\end{array}$ & 12.2 & $14.5 \pm 4.4$ & 17.0 & 72 & $88 \pm 18$ & 100 & 91.6 & $95.8 \pm 5.7$ & 99.6 \\
\hline
\end{tabular}




\begin{tabular}{|c|r|r|r|r|r|r|r|r|r|}
\hline $\begin{array}{c}\text { Eastern } \\
\text { Pacific }\end{array}$ & 7.0 & $9.3 \pm 3.6$ & 11.0 & 64 & $78 \pm 20$ & 92 & 90.5 & $96.0 \pm 9.5$ & 102.9 \\
\hline $\begin{array}{c}\text { South } \\
\text { Indian }\end{array}$ & 6.2 & $8.3 \pm 2.8$ & 10.0 & 59 & $71 \pm 19$ & 79 & 91.5 & $97.6 \pm 8.8$ & 102.5 \\
\hline $\begin{array}{c}\text { North } \\
\text { Atlantic }\end{array}$ & 4.0 & $6.4 \pm 3.1$ & 8.7 & 32 & $51 \pm 25$ & 70 & 84.0 & $92.6 \pm 9.4$ & 98.7 \\
\hline $\begin{array}{c}\text { South } \\
\text { Pacific }\end{array}$ & 4.0 & $5.5 \pm 2.5$ & 7.0 & 56 & $73 \pm 30$ & 82 & 85.2 & $96.8 \pm 12.5$ & 106.8 \\
\hline $\begin{array}{c}\text { North } \\
\text { Indian }\end{array}$ & 1.0 & $1.0 \pm 1.0$ & 2.0 & 30 & $48 \pm 24$ & 70 & 81.2 & $94.0 \pm 17.2$ & 105.0 \\
\hline Global & $\mathbf{4 2 . 5}$ & $\mathbf{4 5 . 0 \pm 9 . 1}$ & $\mathbf{4 9 . 0}$ & $\mathbf{1 0 2 . 0}$ & $\mathbf{7 8} \pm \mathbf{1 9}$ & $\mathbf{1 8 6 . 0}$ & $\mathbf{7 9 . 5}$ & $\mathbf{9 6 . 2} \pm \mathbf{2 1 . 4}$ & $\mathbf{1 1 3 . 6}$ \\
\hline
\end{tabular}

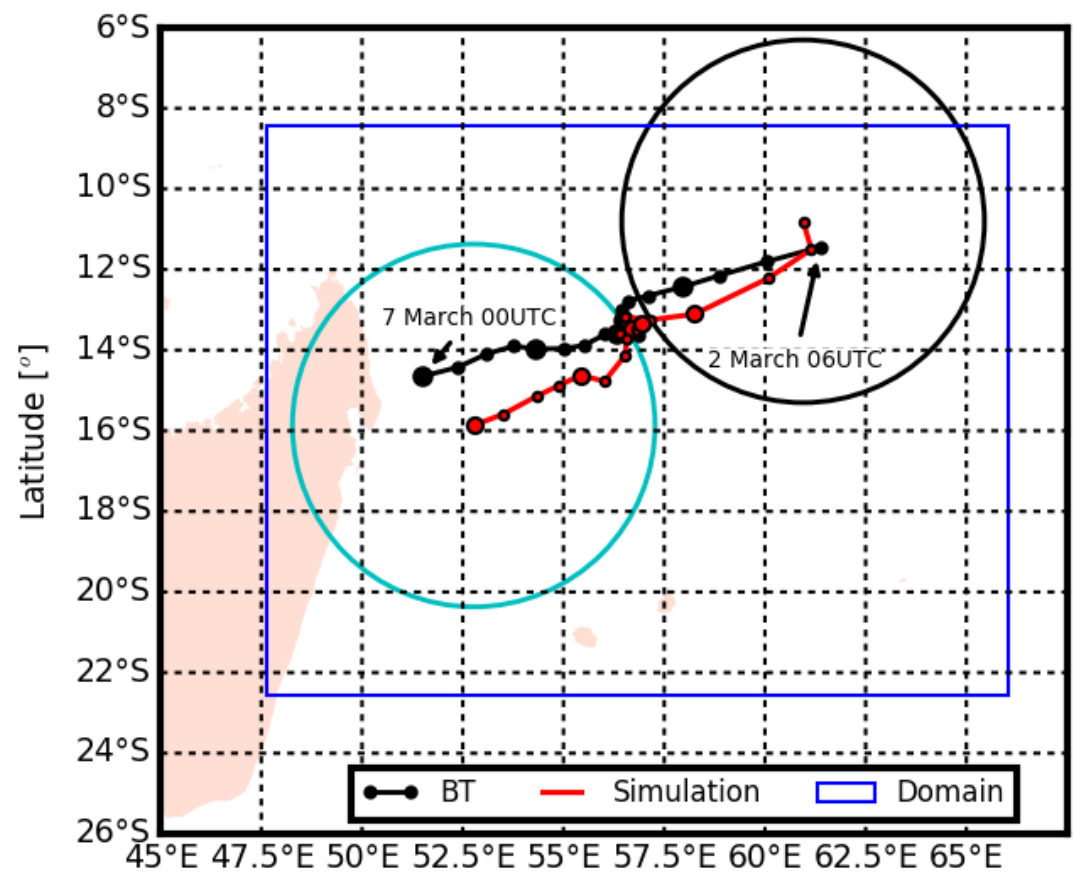

Longitude $\left[{ }^{\circ}\right]$

Figure 1: Simulated (red line) versus RSMC La Réunion best-track (black line). Small dots correspond to 6-hourly locations while large dots correspond to daily locations from 2 March 06UTC to 7 March 00UTC. The 2 circles indicate regions which are used to compute an average water vapor profile around the TC center for the beginning and the end of simulation S4. The domain used in the Meso-NH simulation is in blue and has a 2-km resolution. 


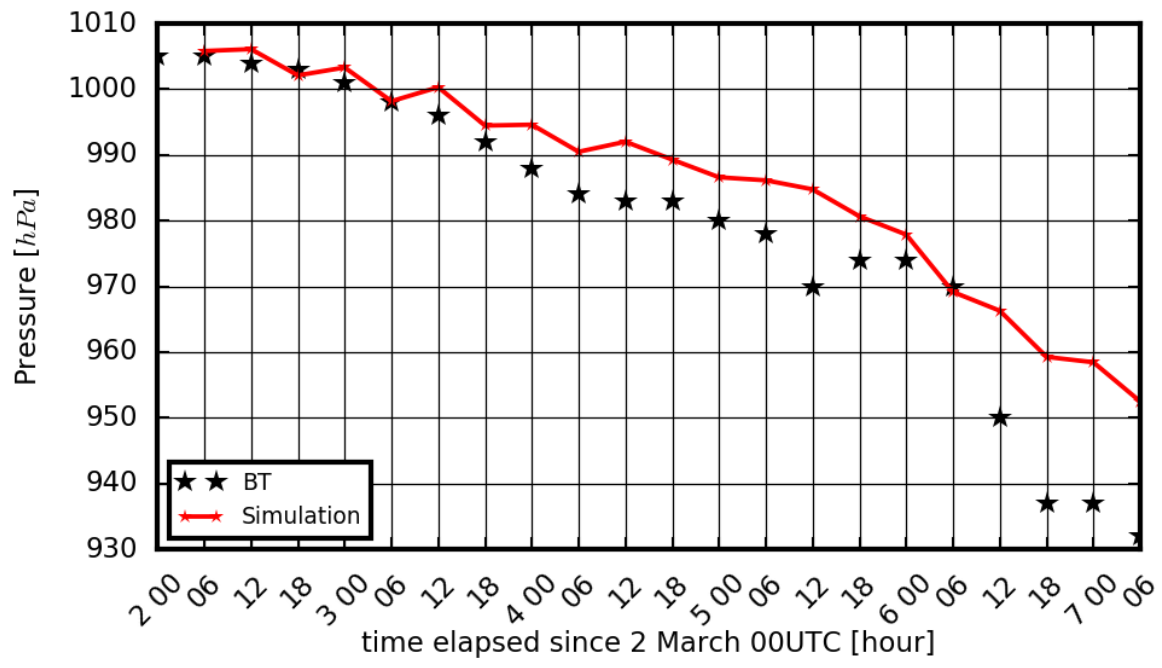

Figure 2: Time series of MSLP in the Meso-NH $2 \mathrm{~km}$ simulation (red line) and in the RSMC La Réunion best-track data (black stars). 6-hourly values of MSLP are shown from 2 March 00UTC to 7 March 00UTC.
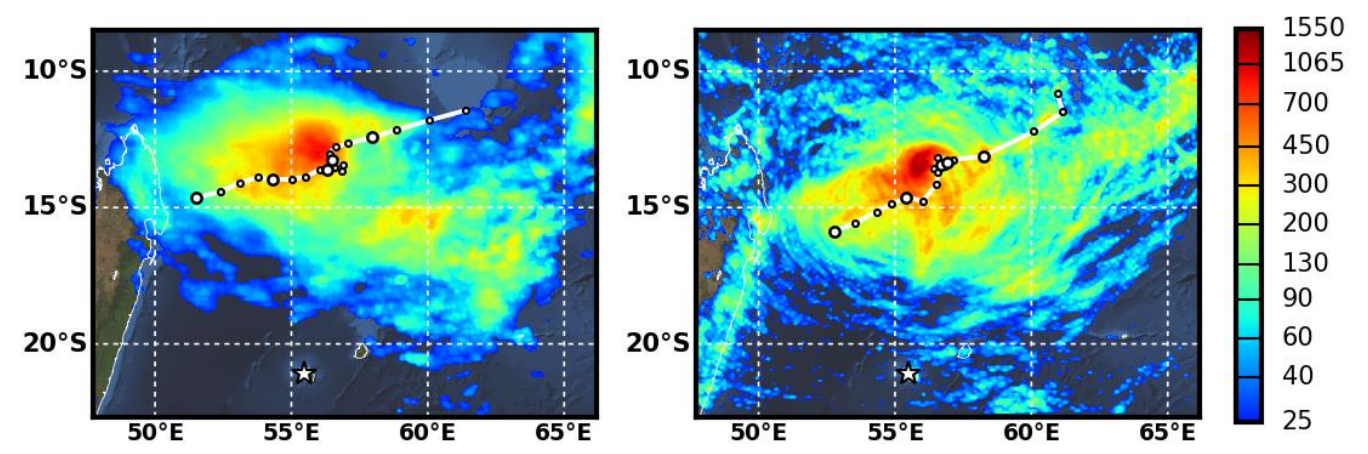

Figure 3: Accumulated precipitation for the period 2 March 06 UTC to 7 March 00UTC. Left: GPM observation. Right: Simulated precipitation. The white line on the left and right panels corresponds to RSMC La Réunion besttrack data and simulated best-track respectively. 

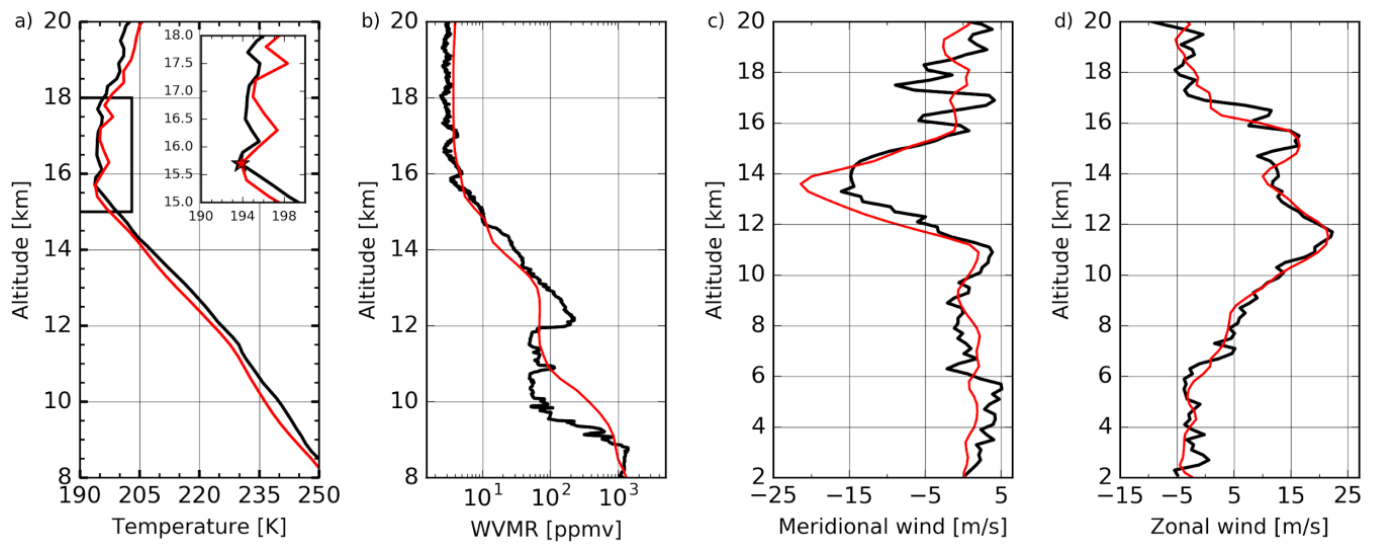

Figure 4: Simulated (red) versus observed (black) profiles at the location of the Maïdo Observatory on 3 March 18 UTC: a) temperature, b) water vapor mixing ratio, c) meridional wind and d) zonal wind. CFH and M10 sonde observations are shown in black while simulated fields are shown in red. On the temperature profiles the location of the observed/simulated Cold Point Tropopause is indicated by black and red stars respectively.
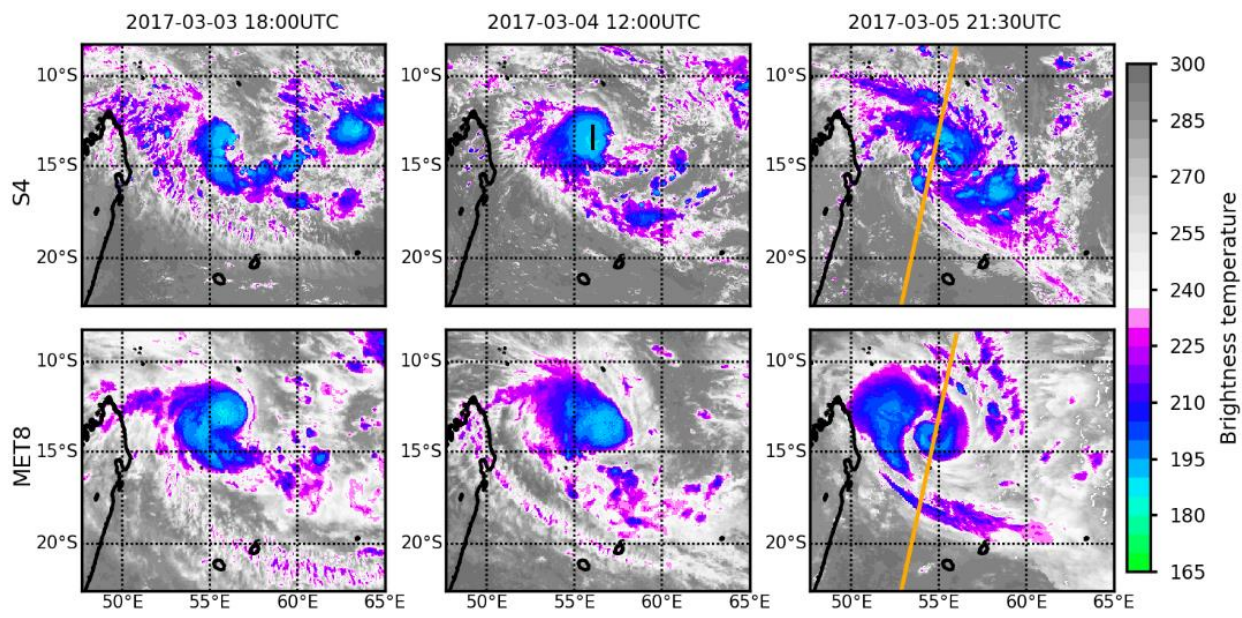

Figure 5: Observed (bottom panels) versus simulated (upper panels) infrared brightness temperature on $3 \mathrm{March}, 18$ UTC (left), 4 March, 12 UTC (middle) and on 5 May, 21:30 UTC. The orange lines correspond to CALIPSO orbit tracks on 5 March at 21:30 UTC. On 4 March, 12 UTC the small vertical black line on the simulated infrared brightness

temperature indicates the south-north cross section shown on Figure 8. 

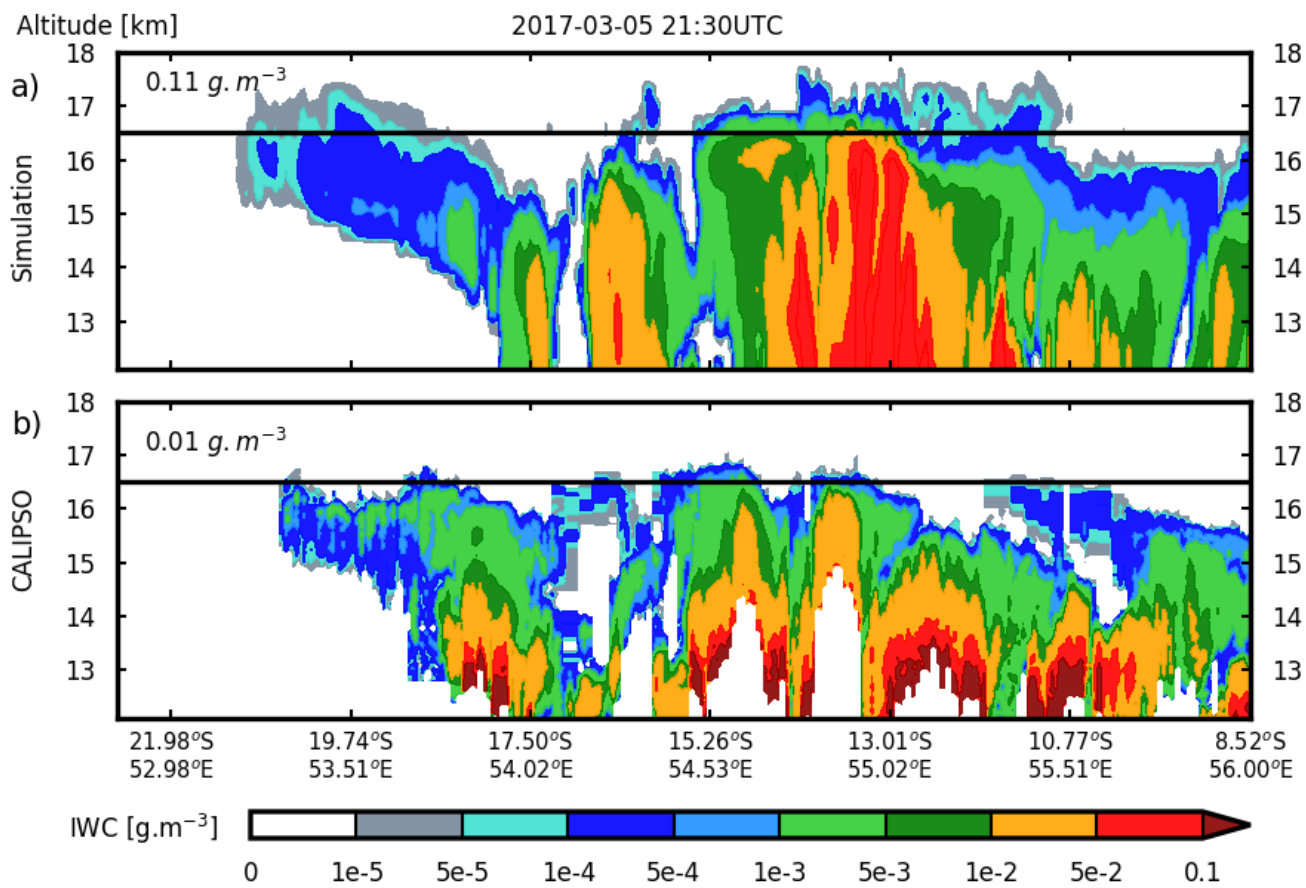

Figure 6: Cross-section (Latitude versus altitude) of CALIOP Ice Water Content (IWC in $\mathrm{g} \mathrm{m}$-3, bottom) along CALIOP track over TC Enawo on 5 March, 2130UTC. The corresponding simulated IWC for S4 is shown on the top panel. The black curves on both panels correspond to the simulated CPT which has a mean height of $16.5 \mathrm{~km}$. The numbers on the top left corner of each plot indicate the mean IWC above the CPT. 


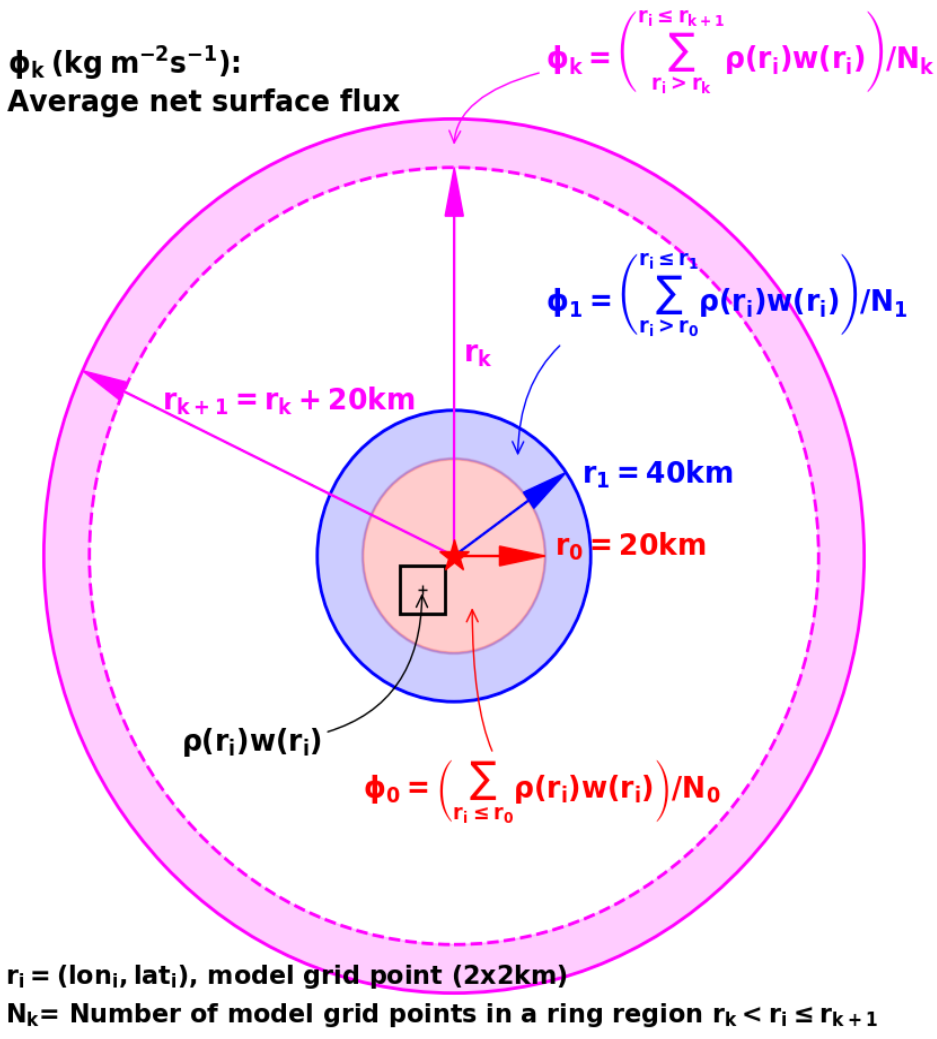

Figure 7: Diagram illustrating the computation of average net mass flux density $\left(\mathrm{kg}^{\mathrm{m}} \mathrm{m}^{-2} . \mathrm{s}^{-1}\right)$ in the simulation. Average net mass fluxes density is computed for ring regions around the TC center (red star) for $20 \mathrm{~km}$ radius increment. 

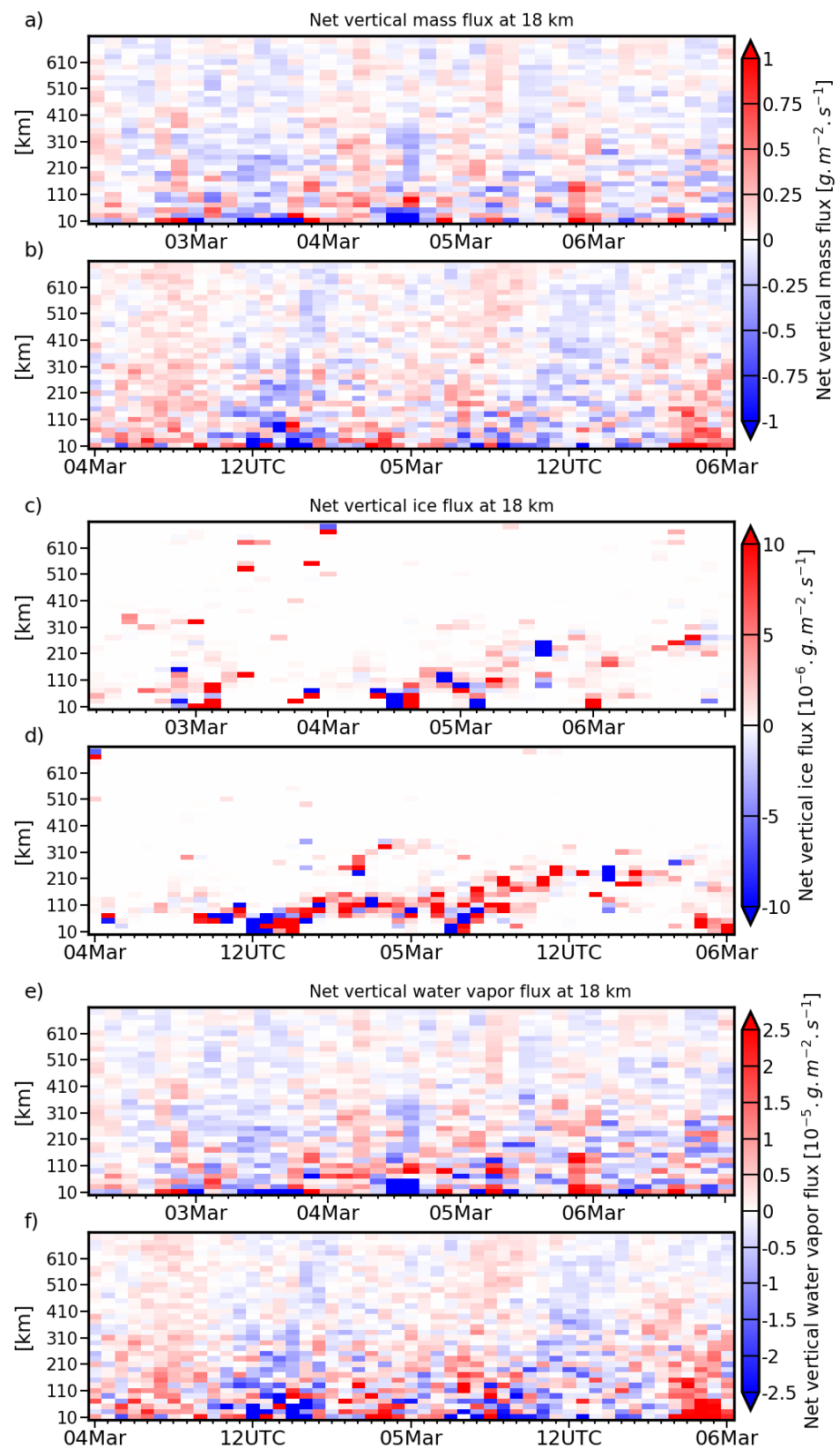

Figure 8: a) Net mass flux at $18 \mathrm{~km}$ in the simulation as a function of time and distance from the TC center. Values were averaged over bins of $20 \mathrm{~km} \times 20 \mathrm{~km}$ for a distance of 0 to $700 \mathrm{~km}$ from the TC center and are shown every 3 hours from 2 March, 06 UTC to 7 March, 00 UTC. b) same as a) but hourly-values from 4 March, 00 UTC to 6 March, 00 UTC while the storm was intensifying over the ocean. c) 3-hourly ice flux values at $18 \mathrm{~km}$ in the simulations from 2 March, 06 UTC to 7 March, 00UTC d) Same as c) but for hourly values from 4 March, 00 UTC to 6 March 6, 00UTC. e) 3-hourly water vapor flux values at $18 \mathrm{~km}$ in the simulations from 2 March, 06 UTC to 7 March, 00 UTC d) Same as c) but for hourly values from 4 March, 00 UTC to 6 March 6, 00 UTC. 


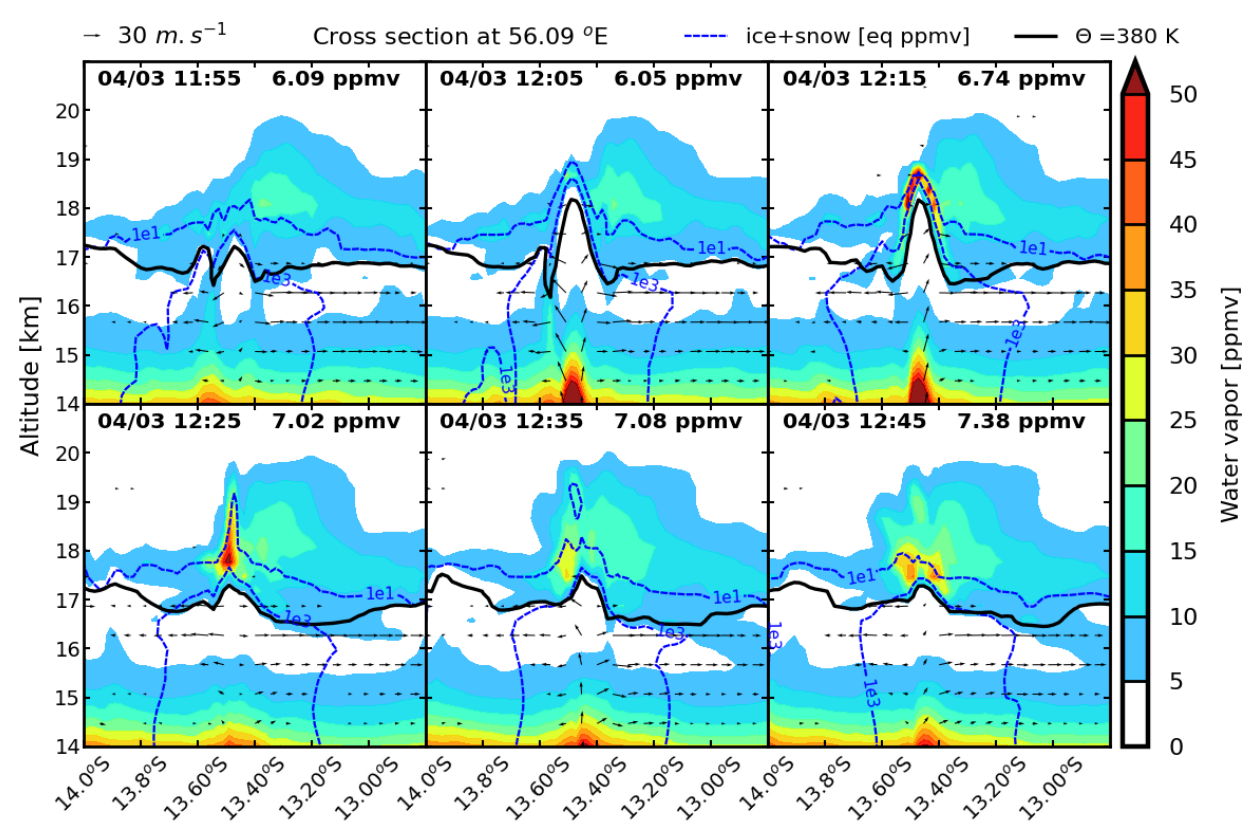

Figure 9: North to south cross sections through the simulated overshooting cloud on 4 March. Plots are every 10 minutes on 4 March from 11:55 UTC to 12:45 UTC. Color contours correspond to the water vapor mixing ratio. Ice mixing ratio (Snow+cloud ice) values ranging from 1 to $1000 \mathrm{ppmv}$ are indicated by blue dashed lines. Black arrows correspond to the zonal/vertical wind fields. The black line in all panels corresponds to the $380 \mathrm{~K}$ isentropic surface. Mean water vapor mixing ratios above the $380 \mathrm{~K}$ surface are indicated in black on the top right corner of each panel. 

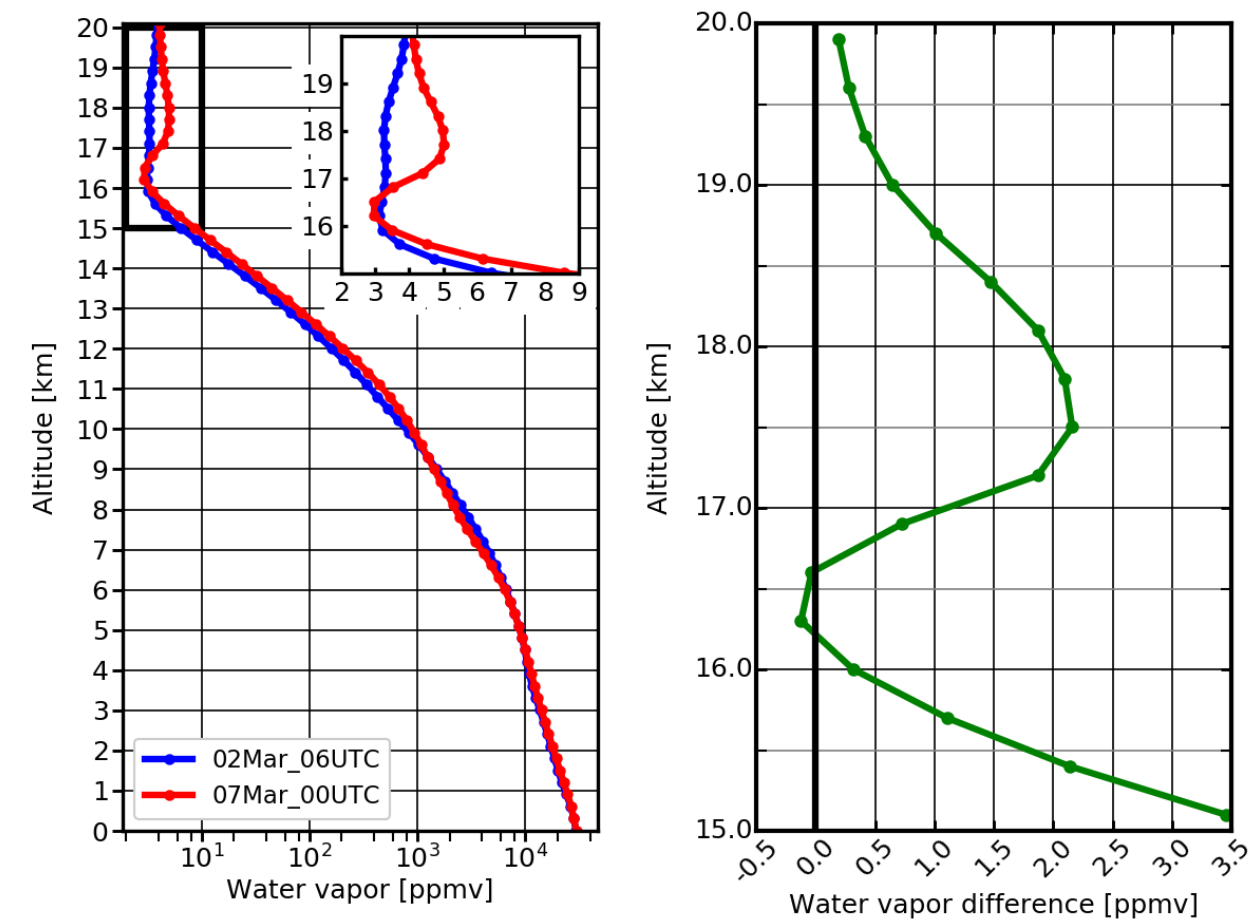

Figure 10: Left, simulated average water vapor mixing ratio profiles on 2 March 06 UTC (blue line) and 7 March 00 UTC (red line). The profiles were averaged over a $500 \mathrm{~km}$ region surrounding Enawo's center which is indicated by the circles on Figure 1. Right, water vapor mixing ratio difference between 2 March 06 UTC and 7 March 00 UTC. The profiles were averaged over a $500 \mathrm{~km}$ region surrounding Enawo's center which is indicated by the circles on Figure 1. 


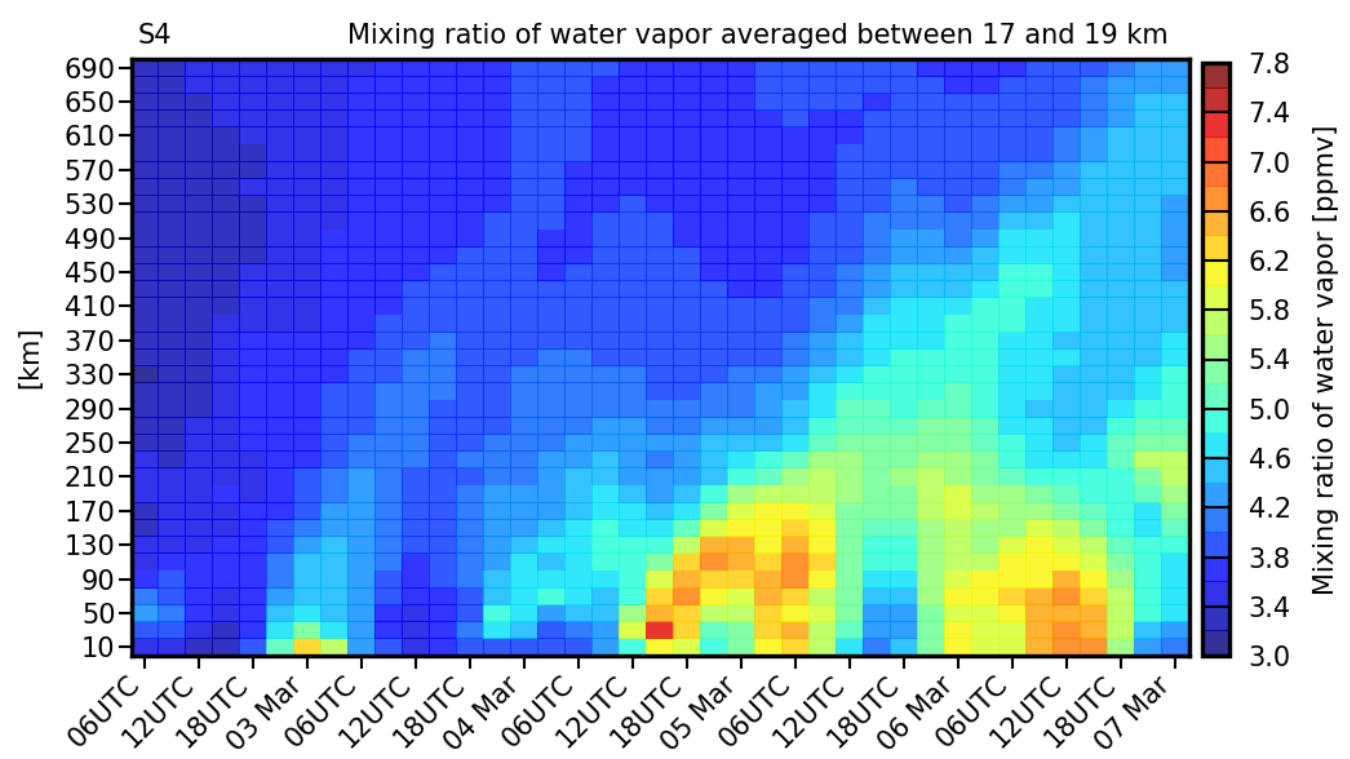

Figure 11: Time versus distance from the TC center of simulated water vapor mixing ratio averaged over the 17-19 km altitude range. Values correspond to bins of $20 \mathrm{~km}$ for a radius of 0 to $700 \mathrm{~km}$ around the TC center and are shown every 3 hours from 2 March 06 UTC to 7 March 00 UTC.

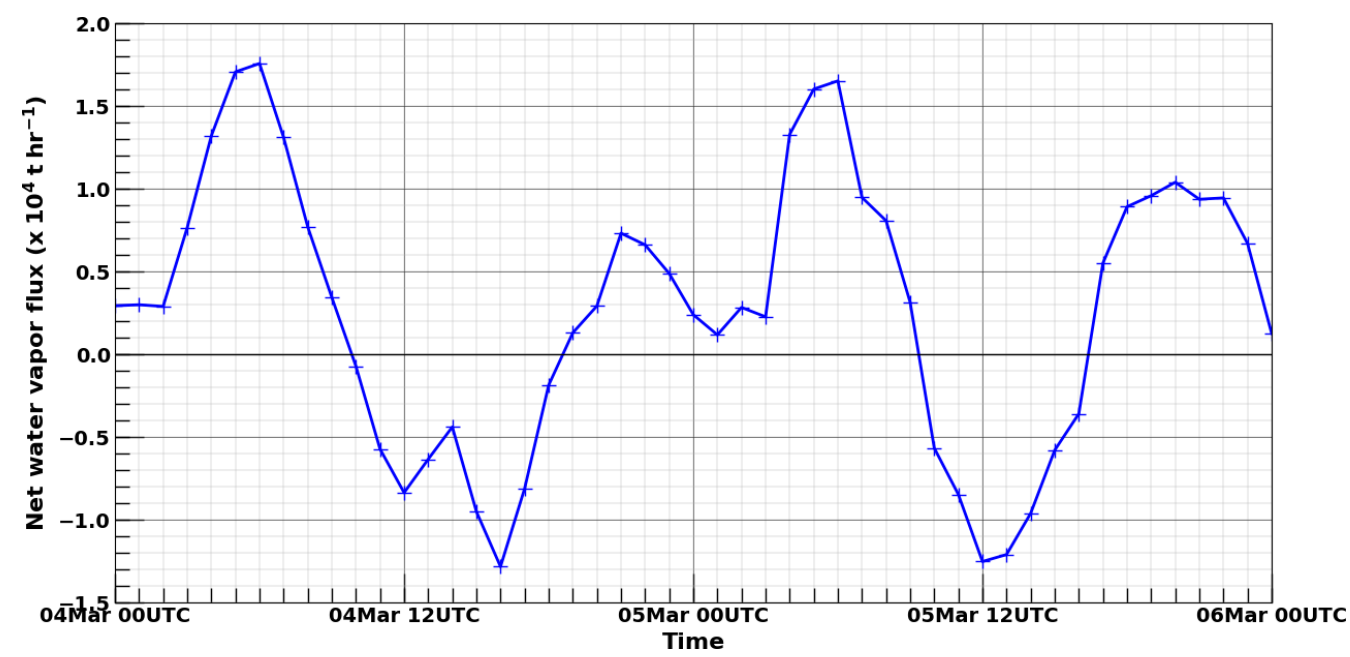

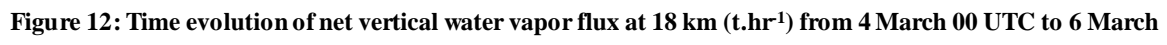
00 UTC. A 700-km region surrounding Enawo's center was used to compute the net vertical water vapor flux for each hourly model output. 